Faculty of Law, Economics and Finance

\title{
CREA
}

\section{RESEARCH REPORT 2013}

CENTRE FOR RESEARCH

IN ECONOMICS \& MANAGEMENT 



\section{Contents}

Presentation 03

1. CREA Staff 04

2. Publications and Scientific Impact 08

Scientific Impact 08

List of Publications 201312

3. Research Programmes 16

Regional Development and Globalisation 16

Macroeconomics and Growth 20

Strategic Interactions and Organisations 24

Corporate Governance and Entrepreneurship 28

Empirical Methods 29

4. Funded Projects 30

5. PhD Training 34

6. Post-Doctoral Projects 35

7. Events and Exchanges 36

Conferences organised at the University of Luxembourg 36 The CREA Lunch Seminars in Economics and Management 36

The CREA Research Seminars 37

Presentations at International Conferences, Workshops, Seminars 38 Short-Term Visits 41

8. CREA in Society 42

Contact 44 



\section{Presentation}

CREA is the Centre for Research in Economics and Management (formerly Centre for Research in Economic Analysis) of the University of Luxembourg. Founded in 1994 within the CRP-Gabriel Lippman Public Research Centre, CREA is now established as one of the departments of the Faculty of Law, Economics and Finance within the University of Luxembourg.

The ambition of CREA is to be recognised as a centre of research excellence in Economics and Management. Its mission includes three tightly connected activities: contribution to top-level scientific research programmes and networks, provision of advanced quantitative education in Economics and Management and the dissemination of knowledge and expertise in Luxembourg and the Greater Region.

Since 2003, CREA has successfully expanded its research activities considerably. Its academic staff has increased from 4 professors in 2005 to 18 in 2013. During the year 2013, CREA members published 29 articles in peer-reviewed international journals, of which 9 were in top journals. According to the Tilburg Research Ranking of Economics Schools, CREA (i.e. University of Luxembourg) ranked 199 out of 949 for the period 2008-2012, placing it in the top $21 \%$ at the world level. This is an excellent achievement given the size of our research staff. CREA members are also active in research networks. In 2013, their ongoing research was presented in about 75 international conferences, workshops or seminars.

Conferences and seminars are a most effective way to promote exchanges across institutions and disseminate research results. The CREA Seminar in Economics and Management is a bimonthly research seminar welcoming speakers from foreign research centres and open to all researchers in Luxembourg. The CREA Conference Talks on Economics are yearly conferences dedicated to a wider audience. In 2013, Prof Paul De Grauwe, John Paulson Chair in European Political Economy at the London School of Economics, gave a talk on Monetary Policy and Global Capital Markets.

The Doctoral School in Economics and Finance (DSEF), a joint venture of CREA and the LSF - Luxembourg School of Finance, was launched in October 2011. The DSEF is designed to give to all PhD students a solid background in both economics and/or finance. It also regularly invites internationally re-known researchers to teach research-frontier topics in finance and economics (Prof Yves Zenou, University of Stockholm; Prof Oded Galor, Brown University; Prof David Martimort, Paris School of Economics; Prof Markus Brunnermeier, Princeton University etc.). The doctoral training in economics also benefits from cooperation with two Luxembourg research institutions, CEPS/INSTEAD and STATEC.

CREA members are also in charge of Bachelor and Master programmes in Economics and/or Management. The Bachelor in Applied
Management is primarily designed for students looking for advanced professional training, while the Bachelor in Economics and Management provides academic training for students aiming for a Master's degree. A Master's in Entrepreneurship and Innovation is offered to students with backgrounds in traditional business disciplines as well as in the humanities and physical sciences. This programme benefits from the support of the Luxembourg Chamber of Commerce. The Master's in Economics and Finance (another joint venture with the LSF) is aimed at students interested in management positions in the financial, banking or insurance sectors and wishing to obtain a comprehensive and sound education in economics and finance. This Master's also includes a research track aimed at prospective $\mathrm{PhD}$ students.

CREA benefits from an extensive network of international academic partnerships. Students, researchers and academics engage in exchange visits at leading universities in Europe, Canada, the USA, Japan, China, Russia and India. Some notable partnerships include the Higher School of Economics in Moscow, Great Lakes Institute of Management in India, Tongji University in Shanghai and Shandong University in China. CREA is also contributing in the University's partnership with a developing country, namely the University of Economic and Management Sciences in Bamako, Mali. In addition, CREA benefits from institutional partnerships form an additional network of cooperation and support for CREA. The Luxembourg Chamber of Commerce, the European Investment Bank, CEPS/INSTEAD and STATEC are part of this group.

Such growth and research achievements over the last 10 years would not have been possible without the commitment of the University of Luxembourg towards highest-quality research. The Luxembourg National Research Fund (FNR) has also contributed to this expansion by funding several important research projects. CREA's expansion will inevitably slowdown in the future. The commitment of its members to the three dimensions of its mission remains stronger than ever however. The international visibility of CREA will be further increased; $\mathrm{PhD}$ programmes reinforced and exchanges with economic actors in Luxembourg intensified. CREA will also expand its education programmes in Management thanks to the financial support of the Luxembourg Chamber of Commerce.

A detailed description of CREA's membership and research activities in 2013 is given in this first full-size research report.
Henri Sneessens Head of CREA 


\section{CREA Staff}

Head

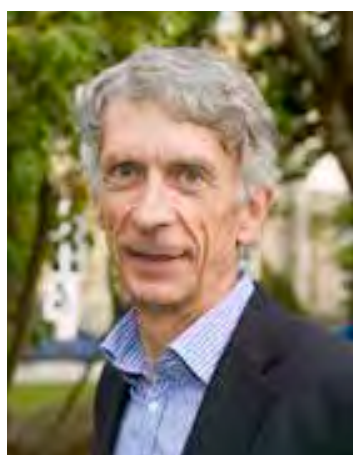

\section{Faculty Members}

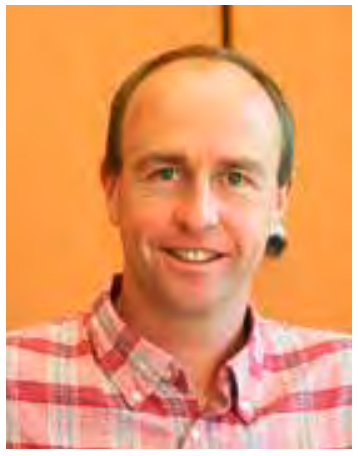

\section{Beine Michel Professor}

$\mathrm{PhD}$ in Economics from the University of Namur (Belgium) in 1991.

Research Interests:

- International Finance

- International Economics

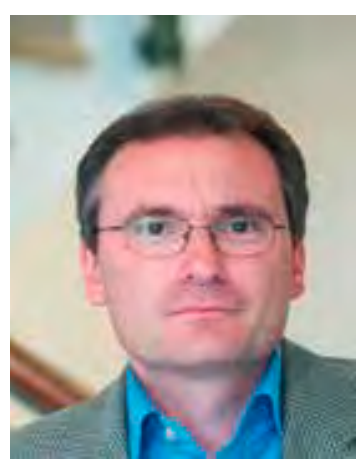

\section{Bourgain Arnaud} Associate Professor

$\mathrm{PhD}$ in Economics from the University of Nancy (France) in 1994.

\section{Research Interests:}

- Economic and Financial Integration

- International Financial Centres

- International Economic Integration of Africa

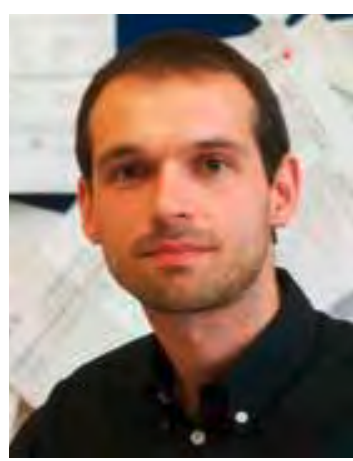

\section{Bertinelli Luisito Associate Professor}

$\mathrm{PhD}$ in Economics from the Université catholique de Louvain (Belgium) in 2003.

\section{Research Interests:}

- Environmental and

Development Economics

- Applied Econometrics

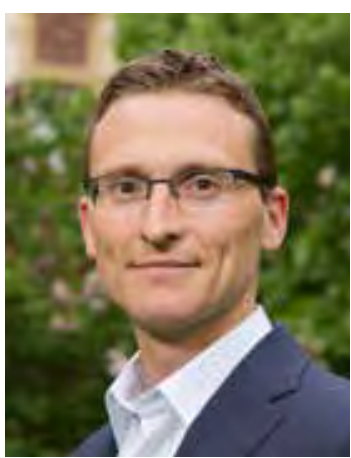

\section{Brauer Matthias} Associate Professor

$\mathrm{PhD}$ in Business Administration from the University of St.Gallen (Switzerland) in 2005.

Research Interests:

- Management

- International Business 


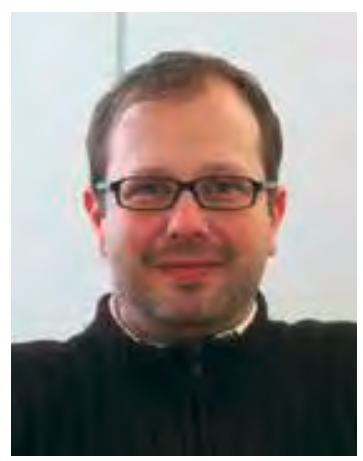

\section{Cosma Antonio Associate Professor}

$\mathrm{PhD}$ in Economics from the Université catholique de Louvain (Belgium) in 2004.

Research Interests:

- Numerical Methods

- Asset Pricing

- Financial Econometrics

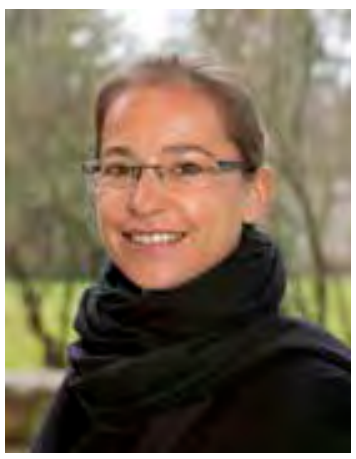

\section{Hussinger Katrin Associate Professor}

$\mathrm{PhD}$ in Applied Economics from the KU Leuven (Belgium) in 2007.

Research Interests:

- Innovation

- Entrepreneurship

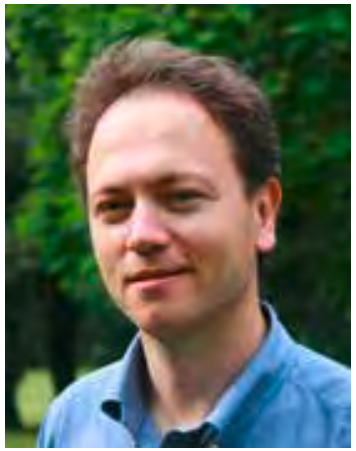

\section{Jonard Nicolas Associate Professor}

$\mathrm{PhD}$ in Economics from the University Louis Pasteur Strasbourg (France) in 1997.

\section{Research Interests:}

- Competition and Cooperation Among Firms

- Firm Behaviour and Learning

- Inter-organisational Networks and Innovation.

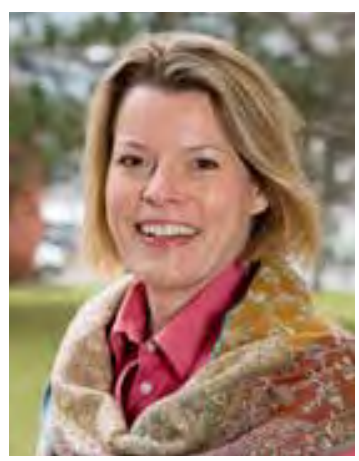

\section{Muessig Anke Professor}

$\mathrm{PhD}$ in Business Administration from the Johann Wolfgang Goethe University Frankfurt (Germany) in 2005.

Research Interests:

- Structure of Audit Markets

- Auditor Reporting

- Auditor Oversight Institutions

- Risk Reporting

- Accounting Conservatism

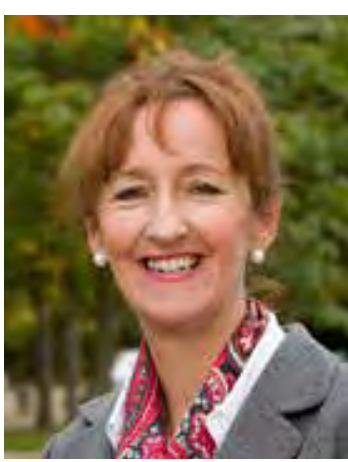

\section{Fletcher Denise Professor}

$\mathrm{PhD}$ in Business and Management from the Nottingham Trent University (UK) in 1997

Research Interests:

- Entrepreneurship

- Family Business

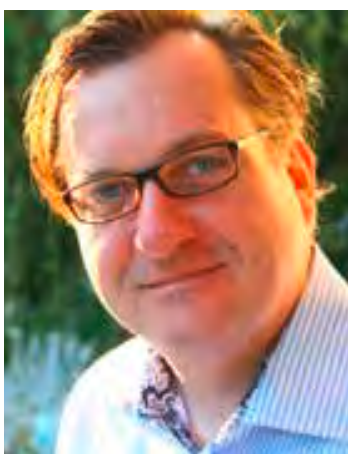

\section{Irmen Andreas Professor}

$\mathrm{PhD}$ in Economics from the University of Lausanne (Switzerland) in 1996.

Research Interests:

- Dynamic Macroeconomics

- Industrial Organisation

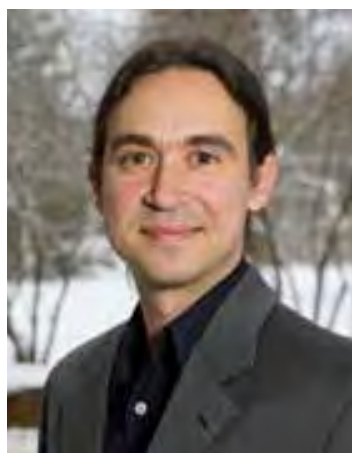

\section{Koulovatianos Christos Professor}

$\mathrm{PhD}$ in Economics from the University of Rochester (USA) in 1999.

Research Interests:

- Macroeconomics

- Economics of Information

- Financial Economics

- Household Finance

- Family Economics

- New Political Economy

- Dynamic Games

- Resource Economics

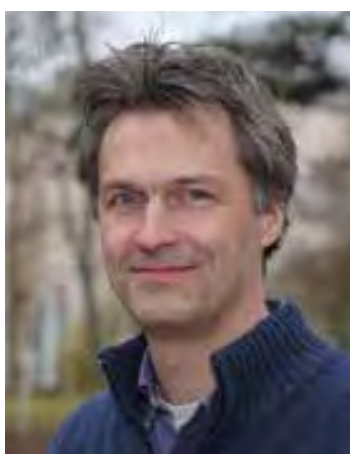

\section{Picard Pierre M} Professor

$\mathrm{PhD}$ in Management Science and Economics from the Université catholique de Louvain (Belgium) in 1998.

Research Interests:

- Public Economics

- Industrial Organisation

- Spatial and Regional Economics

- Economic Geography 


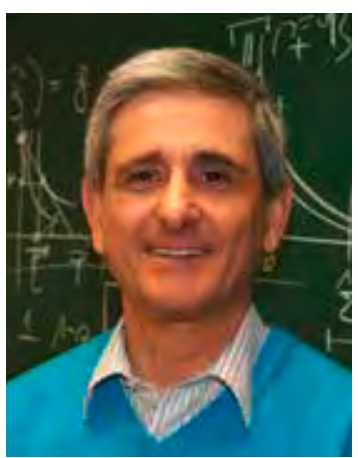

\section{Pieretti Patrice Professor}

$\mathrm{PhD}$ in Economics from the Institut des sciences politiques (Science Po) Paris (France) in 1997.

Research Interests:

- International Economics

- Public Economics

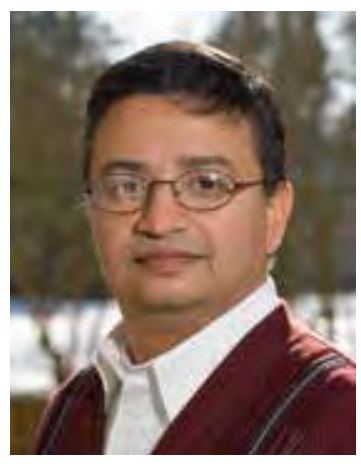

\section{Tripathi Gautam Professor}

$\mathrm{PhD}$ in Economics from Northwestern University (USA) in 1997.

Research Interests:

- Econometrics and Statistics

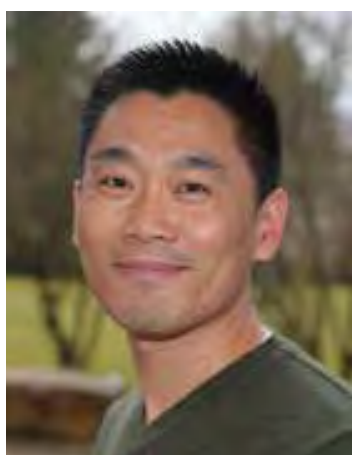

\section{Zou Benteng} Associate Professor

Research Interests:

- Optimisation Theory and Differential Games

- Economic Growth

- Environmental Economics

- Foreign Direct Investment

- International Migration

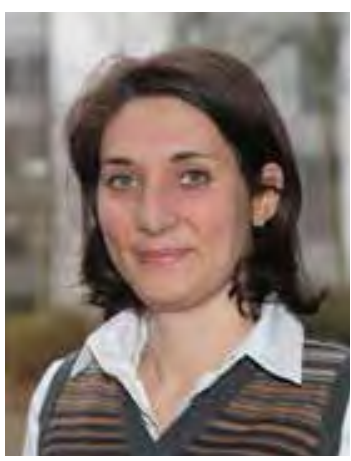

Terraza Virginie Associate Professor

$\mathrm{PhD}$ in Economics from the University of Paris 2 (France) in 2002.

Research Interests:

- Financial Econometrics

- Risk Management

- Market Microstructure and Fund Industry

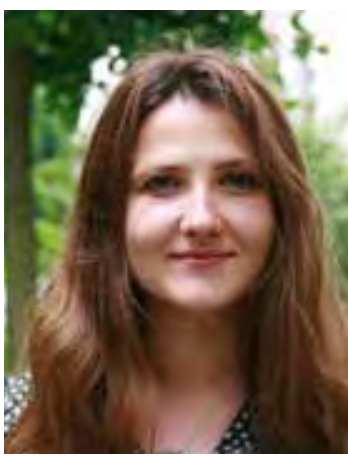

\section{Zanaj Skerdilajda} Associate Professor

$\mathrm{PhD}$ in Economics from the Université catholique de Louvain (Belgium) \& Università degli Studi di Siena (Italy) in 2008.

Research Interests:

- Public Economics

- Industrial Organisation

- International Economics

$\mathrm{PhD}$ in Mathematics from Peking University (China) in 1999.

$\mathrm{PhD}$ in Economics from the Université catholique de Louvain (Belgium) in 2005. 


\section{Guest Professors}

Bessant John

(Business School, University of Exeter, UK)

Reinesch Gaston

(Banque centrale du Luxembourg, Luxembourg)

Thisse Jacques

(CORE ${ }^{1}$, Université catholique de Louvain, Belgium)

\section{Post-docs}

Carpantier Jean-François

(PhD in Economics and Management, Université catholique de Louvain, Belgium, 2012)

\section{Litina Anastasia}

( $\mathrm{PhD}$ in Economics, University of Macedonia, Greece, 2010)

Nguyen Ha Manh

(PhD in Economics, University of Colorado Boulder, USA, 2011)

Tampieri Alessandro**

(PhD in Economics, University of Leicester, UK, 2011)

\section{PhD Students}

Adiguna Rocky
Chevallier Claire-Océane
Delogu Marco
Doherr Thorsten $^{* * *}$
El Jouedi Sarah
Han Yutao
Loehlein Lukas
Mavridis Dimitrios
Perego Erica
Pietsch Christian
Pulina Giuseppe**
Reyt Jean-Nicolas
Schumann Martin
Tabakovic Amer
Tryba Anne***
Wan Xi

\section{Scientific Collaborators}

\author{
Margherita Antonia \\ Schwartz Déborah \\ Bratean Diana (FNR project) \\ Souy Bénédicte (FNR project)
}

\section{Administrative Staff}

Ferreira Elisa

Henrioul Anne-Sophie

Legrand Marina

\section{Extramural Research Fellows}

Gabszewicz Jean

CORE, Université catholique de Louvain (Belgium)

Hamano Masashige

Sophia University, Yotsuya Campus (Japan)

Lodigiani Elisabetta

Università delgi Studi di Milano (Italy)

Marhuenda Francisco

Universidad Carlos III, Madrid (Spain)

Morriconi Simone

Universita Cattolica del Sacro Cuore, Milano (Italy)

Valila Timo

European Investment Bank, Economic Advisor (Luxembourg)

Vermeulen Robert

Nederlandsche Bank (The Netherlands) 


\section{Publications}

\section{and Scientific Impact}

CREA's research output in 2013 can be summarised as follows:

- 27 publications in peer-reviewed international journals, plus 1 forthcoming;

- includes publications in the Strategic Management Journal and the following top international journals listed in the Tilburg ranking : Economics Letters, Journal of Economic Behavior and Organization, Journal of Economic Dynamics and Control, Journal of Economic Theory, Journal of Public Economics, Scandinavian Journal of Economics;

- 2 authored books, 1 edited book and 1 book chapter;

- 38 discussion papers, of which 29 in the CREA Discussion Paper Series;

- 75 communications at academic conferences and workshops.

The academic impact of CREA's research can be further illustrated by the following statistics:

- 24 papers published by faculty members have received more than 50 citations in Google Scholar, 18 papers more than 20 citations in Scopus;

- The average number of citations per year for the 17 faculty members of CREA is 35.9 (it is 96.7 for the top- 5 authors), the average $h$-index is 9.2 (16.4 for the top-5).

More detailed measures of scientific impact and the list of publications are given below.

\section{A. Scientific Impact}

The quality and the academic impact of research activities can be assessed in several ways. Quantitative measures are now frequently used to rank research institutions and to measure the impact of scientific publications. Quantitative measures should of course be interpreted with care and in context. Still they are a most useful tool to help evaluate research performance. Several metrics are available, and it is always recommended not to focus on a single one. We report here on a few quantitative indicators and measures regularly used in our profession.

\section{Ranking of Research Institutions}

Tilburg University Economics Ranking: CREA in the top 21\%

The Tilburg ranking is one of the most famous worldwide research rankings of Economics departments. The ranking is based on the number of publications in 35 leading economics journals. The count is based on the affiliation mentioned in the published papers. Because CREA is a pretty young department (more than half of its current faculty members joined CREA after 2008), and also because management journals are not included in the count, the true publication record of current CREA members is underestimated. However, the ranking still provides useful information.

In the Tilburg ranking 2008-2012, the University of Luxembourg (actually CREA $^{2}$ ) is ranked 199 out of 949, which places CREA in the top $21 \%$ at the world level.

(see https://econtop.uvt.nl/rankingsandbox.php) 


\begin{tabular}{|c|c|c|c|c|c|c|c|}
\hline & 2008 & 2009 & 2010 & 2011 & 2012 & 2013 & TOTAL \\
\hline 1. Economic Journal & 1 & 1 & - & - & - & - & 2 \\
\hline 2. Economics Letters & 1 & - & 1 & 1 & 1 & 1 & 5 \\
\hline 3. International Economic Review & - & - & 1 & - & - & - & 1 \\
\hline 4. Journal of Applied Econometrics & 1 & - & - & - & - & - & 1 \\
\hline 5. Journal of Business and Economic Statistics & - & 1 & - & - & - & - & 1 \\
\hline 6. Journal of Development Economics & - & - & - & 1 & - & - & 1 \\
\hline 7. Journal of Econometrics & - & 1 & - & 1 & 1 & - & 3 \\
\hline 8. Journal of Economic Behavior and Organization & - & - & - & - & 1 & 1 & 2 \\
\hline 9. Journal of Economic Dynamics and Control & - & - & 2 & 1 & - & 2 & 5 \\
\hline 10. Journal of Economic Theory & - & 1 & - & 1 & - & 1 & 3 \\
\hline 11. Journal of International Economics & - & - & 1 & 2 & - & - & 3 \\
\hline 12. Journal of Public Economics & - & - & - & 1 & - & 2 & 3 \\
\hline 13. Journal of Urban Economics & - & - & - & 1 & - & - & 1 \\
\hline 14. Journal of the European Economic Association & 1 & - & - & - & - & - & 1 \\
\hline 15. Review of Economic Dynamics & - & - & - & - & 1 & - & 1 \\
\hline 16. Review of Economics and Statistics & - & - & 2 & - & - & - & 2 \\
\hline 17. World Bank Economic Review & 1 & - & - & - & - & - & 1 \\
\hline 18. Econometric Theory & - & - & - & 1 & - & - & 1 \\
\hline 19. Economic Theory & - & 1 & 1 & - & - & - & 2 \\
\hline 20. Journal of Banking and Finance & - & - & 1 & - & - & - & 1 \\
\hline 21. Journal of Environmental Economics \& Management & 1 & - & - & - & - & - & 1 \\
\hline 22. Journal of Macroeconomics & 1 & - & - & - & - & - & 1 \\
\hline 23. Regional Science \& Urban Economics* & - & - & - & - & 2 & - & 2 \\
\hline 24. Scandinavian Journal of Economics & - & - & - & - & 1 & 1 & 2 \\
\hline 25. World Development & - & - & - & 1 & - & - & 1 \\
\hline 26. Academy of Management Review* & - & 1 & - & - & - & - & 1 \\
\hline 27. Management Science* & - & - & 1 & - & - & - & 1 \\
\hline 28. Strategic Management Journal* & - & - & - & - & - & 1 & 1 \\
\hline 29. European Journal of Operations Research* & 1 & - & - & - & - & - & 1 \\
\hline TOTAL TOP JOURNALS & 8 & 6 & 10 & 11 & 7 & 9 & 51 \\
\hline ALL PEER-REVIEWED JOURNALS & 18 & 23 & 19 & 29 & 19 & 29 & 137 \\
\hline
\end{tabular}

Table 1 reports on the number of all publications by CREA members in journals included in the Tilburg ranking (the top 35 plus the complementary list), plus a few other top journals (marked with an asterisk), mainly top journals in management, a field not covered by the Tilburg ranking. Over the period 2008-2013, CREA members published 137 articles in peer-reviewed international journals, of which 51 in top journals.

\section{Economics Departments and Institutions Rankings at IDEAS:}

An alternative measure of performance is provided by the ranking of Economics Departments and research institutions published by IDEAS. The ranking is based on RePEc (Research Papers in Economics $)^{3}$, the largest bibliographic database dedicated to Economics and available freely on the internet. It is based on 6,395 institutions with 38,965 registered authors. The ranking uses a
Table 1:

Publications in top journals (those not included in the Tilburg selection - mainly top journals in management - are marked with an asterisk) number of criteria (including citations) and includes all research papers written by the current members of an institution over the last 10 years, provided they are registered with RePEc.

As of March 2014, CREA was ranked in the top $24 \%$ of Economics Departments and in the top $6 \%$ of Economic Institutions at the world level.

(see http://ideas.repec.org/top/top.econdept.html and http://ideas.repec.org/top/top.inst.all.html).

${ }^{3}$ RePEc (Research Papers in Economics) is a collaborative effort of hundreds of volunteers in 81 countries to enhance the dissemination of research in Economics and related sciences. The heart of the project is a decentralised bibliographic database of working papers, journal articles, books, book chapters and software components, all maintained by volunteers. 


\section{Citations}

The visibility of a given piece of work can be assessed by the reputation of the journal where the article is published. This is the basis of the Tilburg ranking. Another way to measure how influential a paper may have been is by looking at the number of citations. The advantage of that measure of impact is that it does not depend on a closed list of journals. We report here on two different measures of citations, Scopus (which only considers citations of published articles in scientific journals) and the HPP index (which includes discussion papers)

\section{Scopus}

Scopus is the largest abstract and citation database of peer-reviewed literature. It delivers the most comprehensive overview of the world's research output (mainly peer-review journals, book series, conference proceedings) in science, technology, medicine, social sciences, as well as arts and humanities.

(see http://www.elsevier.com/online-tools/scopus)

18 articles published by CREA members over the period 20042014 have so far received more than 20 citations, which gives an h-index of 19 for CREA as a whole (citations in working papers and unpublished papers are not included). The 18 most cited articles are the following:

- 229 citations for Cowan R \& Jonard N (2004). Network Structure and the Diffusion of Knowledge. Journal of Economic Dynamics \& Control, 28, 1557-1575.

- 103 citations for Beine M, Docquier F and Rapoport H (2008). Brain Drain and Human Capital Formation in Developing Countries: Winners and Losers, Economic Journal, Volume 118, Issue 528, pp.631-652.

- 66 citations for Jonard N, Cowan R \& Zimmermann J-B (2007). Bilateral Collaboration and the Emergence of Networks. Management Science, 53(7), 1051-1067.

- 60 citations for Hussinger K \& Arnold J-M (2005). Export Behavior and Firm Productivity in German Manufacturing - A Firm-level Analysis. Review of World Economics 141(2), 219-243.

- 57 citations for Fletcher DE (2006). Entrepreneurial Processes and the Social Construction of Opportunity. Entrepreneurship and Regional Development, 18(5), 421-440.

- 47 citations for Cowan R, Jonard N \& Ozman M (2004). Knowledge Dynamics in a Network Industry. Technological Forecasting and Social Change, 71, 469-484.

- 47 citations for Barrios S, Bertinelli L \& Strobl E (2006). Climatic Change and Rural-Urban Migration: The Case of Sub-Saharan Africa. Journal of Urban Economics, 60(3), 357-371.
- 34 citations for Beine M, Docquier F \& Rapoport H (2007). Measuring International Skilled Migration: A New Database Controlling for Age of Entry. World Bank Economic Review, 21(2), 249-254.

- 34 citations for Bertinelli L \& Strobl E (2005). The Environmental Kuznets Curve Semi-parametrically Revisited. Economics Letters, 88(3), 350-357.

- 30 citations for Beine M, Docquier F \& Ozden C (2011). Diasporas. Journal of Development Economics, 95, 30-41.

- 25 citations for Bertinelli L \& Decrop J (2005). Geographical Agglomeration: The Case of Belgian Manufacturing Industry. Regional Studies, 39 (5), 567-583.

- 24 citations for Hussinger K, Czarnitzki D \& Glanzel W (2007). Patent and Publication Activities of German Professors: An Empirical Assessment of Their Co-Activity. Research Evaluation 16(4), 311-319.

- 23 citations for Fletcher DE (2007). 'Toy Story': The Narrative World of Entrepreneurship. Journal of Business Venturing, 22(5), 649-672.

- 22 citations for Cosma A, Beine M \& Vermeulen R (2010). The Dark Side of Global Integration: Increasing Tail Dependence. Journal of Banking and Finance, 34(1), 184-192.

- 22 citations for Cowan R \& Jonard N (2009). Knowledge Portfolios and the Organisation of Innovation Networks. Academy of Management Review, 34, 101-122.

- 21 citations for Bertinelli L \& Black D (2004). Urbanisation and Growth. Journal of Urban Economics, 56(1), 80-96.

- 21 citations for Barrios S, Bertinelli L, Strobl E \& Teixeira A-C (2005). The Dynamics of Agglomeration: Evidence from Ireland and Portugal. Journal of Urban Economics, 57(1), 170-188.

- 20 citations for Irmen A \& Kuehnel J (2009). Productive Government Expenditure and Economic Growth. Journal of Economic Surveys, 23(4), 692-733.

\section{Harzing's Publish or Perish Index (HPP)}

The Harzing's Publish or Perish index (HPP) of citations ${ }^{4}$ includes discussion papers as well as published articles. This alternative measure is a most useful complement to Scopus. In economics and management, the delay between the first circulation of a piece of research and its final publication in a peer-reviewed journal is typically measured in years. A 5 to

${ }^{4}$ Publish or Perish is a software program that retrieves and analyses academic citations. See http://www.harzing.com/pop.htm\#about 
10-year lag is not unusual, especially for publications in top journals. Discussion paper series are in this context a most important tool to disseminate new research results. The HPP index specifically takes this into account.

HPP considers scholarly citations and calculates a number of citations and impact statistics by field. Raw citations are obtained from Google Scholar. We use 5 indicators: the h-index (a scientist has an index score of $h$ if $h$ of his/her $N$ papers have at least $h$ citations each), the g-index (a variant of the h-index giving more weight to highly-cited articles), the average number of citations per year, the number of citations of each author's most cited paper, and the number of papers with at least 50 citations.

The statistics below were computed on 10 February 2014. During the period 1996-2013 the average score of the current 18 faculty members and the top- 5 authors are as follows:

- average h-index: $\mathbf{9 . 1 7}$ (16.4 for the top-5 authors);

- average g-index: 17.95 (36.8 for the top-5 authors);

- average number of citations per year: $\mathbf{3 5 . 8 8}$

(96.69 for the top-5 authors);

- average number of citations of each author's most cited paper: 120.88 ( 320.20 for the top-5 authors);

- number of papers with at least 50 citations: 24.

\section{The 24 most cited articles published by CREA members are the following:}

- 667 citations for Cowan R \& Jonard N (2004). Network Structure and the Diffusion of Knowledge. Journal of Economic Dynamics \& Control, 28, 1557-1575.

- 392 citations for Beine M, Docquier F \& Rapoport H (2008). Brain Drain and Human Capital Formation in Developing Countries: Winners and Losers, Economic Journal, 118 (528), 631-652.

- 250 citations for Hussinger K \& Arnold J-M (2005). Export Behavior and Firm Productivity in German Manufacturing - A Firm-level Analysis. Review of World Economics, 141(2), 219-243.

- 180 citations for Beine M, Docquier F \& Ozden C (2011). Diasporas. Journal of Development Economics, 95, 30-41.

- 178 citations for Jonard N, Cowan R \& Zimmermann J-B (2007). Bilateral Collaboration and the Emergence of Networks. Management Science, 53(7), 1051-1067.

- 162 citations for Hussinger K (2008). R\&D and Subsidies at the Firm Level: An Application of Parametric and Semi-parametric Two step Selection Models. Journal of Applied Econometrics, 23(6), 729-747.
- 160 citations for Cowan R, Jonard N \& Ozman M (2004). Knowledge Dynamics in a Network Industry. Technological Forecasting and Social Change, 71, 469-484.

- 149 citations for Tripathi G, Ahn A, \& Kitamura Y (2004). Empirical Likelihood Based Inference in Conditional Moment Restriction Models. Econometrica, 72, 1667-1714.

- 143 citations for Barrios S, Bertinelli L \& Strobl E (2006). Climatic Change and Rural-Urban Migration: The Case of Sub-Saharan Africa. Journal of Urban Economics, 60(3), 357-371.

- 123 citations for Hussinger K, Czarnitzki D (2004). The link between R\&D Subsidies, R\&D Spending and Technological Performance. ZEW Discussion Papers 04-56 (forthcoming in The Journal of Industrial Economics).

- 110 citations for Beine M, Docquier F \& Rapoport H (2007). Measuring International Skilled Migration: A New Database Controlling for Age of Entry. World Bank Economic Review, 21(2), 249-254.

- 109 citations for Hussinger K \& Arnold J-M (2010). Exports versus FDI in German Manufacturing: Firm Performance and Participation in International Markets. Review of International Economics, 18(4), 595-606.

- 105 citations for Bertinelli L \& Strobl E (2005). The Environmental Kuznets Curve Semi-parametrically Revisited. Economics Letters, 88(3), 350-357.

- 97 citations for Picard PM, Zeng DZ (2005). Agricultural Sector and Industrial Agglomeration. Journal of Development Economics 77(1), 75-106.

- 82 citations for Jonard N, Cowan R (2006). Evolving Networks of Inventors. Journal of Evolutionary Economics, 16, 155-174.

- 76 citations for Brauer M, Schmidt SL (2006). Corporate Governance: An International Review, 16, 13-22.

- 70 citations for Brauer M (2006). What Have We Acquired and What Should We Acquire in Divestiture Research? A Review and Research Agenda. Journal of Management, 32(6), 751-785.

- 69 citations for Cowan R \& Jonard N (2009). Knowledge Portfolios and the Organisation of Innovation Networks. Academy of Management Review, 34, 101-122.

- 67 citations for Bertinelli L \& Decrop J (2005). Geographical Agglomeration: the Case of Belgian Manufacturing Industry. Regional Studies, 39 (5), 567-583. 
- 65 citations for Beine M, Lahaye J, Laurent S, Neely CJ and Palm C (2007). Central Bank Intervention and Exchange Rate Volatility, its Continuous and Jump Components. International Journal of Finance \& Economics. Special Issue: Exchange Rate Intervention, 12(2), 201-223.

- 65 citations for Irmen A \& Kuehnel J (2009). Productive Government Expenditure and Economic Growth. Journal of Economic Surveys, 23(4), 692-733.

- 60 citations for Bertinelli L, Barrios S \& Strobl E (2010). Trends in Rainfall and Economic Growth in Africa: A Neglected Cause of the African Growth Tragedy. The Review of Economics and Statistics, 92(2), 350-366.

- 60 citations for Hussinger K, Grimpe C (2008). Pre-empting Technology Competition through Firm Acquisition. Economics Letters, 100(2), 189-191.

- 59 citations for Hussinger K (2006). Is Silence Golden? Patents versus Secrecy at the Firm Level. Economics of Innovation and New Technology, 15(8), 735-752.

- 58 citations for Hussinger K, Czarnitzki D \& Glänzel W (2009). Heterogeneity of Patenting Activity and its Implications for Scientific Research. Research Policy, 38(1), 26-34.

- 52 citations for Barrios S, Bertinelli L, Strobl E \& Teixeira A-C (2005). The Dynamics of Agglomeration: Evidence from Ireland and Portugal. Journal of Urban Economics, 57(1), 170-188.

\section{RePEc Authors' Access Statistics}

The international visibility of an institution and its researchers can also be assessed nowadays by the number of downloads or abstract views on the internet. Such authors' access statistics can be computed from the above-mentioned RePEc bibliographic database (only for registered authors). For the last 12 months (as of 3 March 2014), we obtain the following average numbers of abstract views and file downloads per registered author (top- 5 authors between parentheses):

\begin{tabular}{|lcc|}
\hline $\begin{array}{l}\text { Last } 12 \text { Months Statistics per Author } \\
\text { as of } 3 \text { March } 2014\end{array}$ & $\begin{array}{c}\text { Abstract } \\
\text { Views }\end{array}$ & $\begin{array}{c}\text { File } \\
\text { Downloads }\end{array}$ \\
\hline Working Papers & $1,096(2,347)$ & $361(783)$ \\
\hline Published Articles & $271(643)$ & $79(188)$ \\
\hline
\end{tabular}

\section{B. List of Publications 2013}

\section{Books}

- Terraza V \& Toque C (2013). Analyse statistique pour la gestion bancaire et financière. De Boeck, Bruxelles, Belgique.

- Terraza V \& Razafitombo H (Eds), (2013). Understanding Investment Funds- Insights from Performance and Risk Analysis. London, England: Palgrave.

- Vermeulen Wessel (2013). Essays on Dutch Disease and International Finance. The Netherlands: Datawyse Maastricht.

\section{Articles Published or Forthcoming in Peer-reviewed Journals}

- Auriol E \& Picard PM (2013). A Theory of BOT Concession Contracts. Journal of Economic Behavior \& Organization, 89, 187-209.

- Baum J, Cowan R \& Jonard N (2013). Does Evidence of Network Effects on Firm Performance in Pooled Cross-Section Support Prescriptions for Network Strategy? Strategic Management Journal, doi: 10.1002/smj.2133 (forthcoming 35: 652-667, May 2014).

- Beine M, Docquier F \& Schiff M (2013). International Migration, Transfer of Norms and Home Country Fertility. Canadian Journal of Economics, 46(4), 1406-1430.

- Beine M \& Salomone S (2013). Network Effect in International Migration: Does Education Matter More than Gender? Scandinavian Journal of Economics, 115(2), 354-380.

- Beine M \& Sekkat K (2013). Skilled Migration and the Transfer of Institutional Norms. IZA : Journal of Migration, 2(9), 2-19.

- Bertinelli L, Cardi 0 \& Sen P (2013). Deregulation Shock in Product Market and Unemployment. Journal of Economic Dynamics \& Control, 37(4), 711-734.

- Bertinelli L \& Strobl E (2013). Quantifying the Local Economic Growth Impact of Hurricane Strikes: An Analysis from Outer Space for the Caribbean. Journal of Applied Meteorology \& Climatology, 52(8), 1688-1697.

- Brauer M \& Heitmann M (2013). Determinants and Temporal Dynamics of Strategic Divergence: Evidence from Europe. Journal of World Business, 48(1), 110-121.

- Breuillé M-L \& Zanaj S (2013). Mergers in Fiscal Federalism. Journal of Public Economics, 105, 11-22.

- Brueckner J \& Picard PM (2013). Airline Alliances, Carve-Outs and Collusion. Review of Network Economics, 12(2), 211. 
- Carpantier J-F \& Samkharadze B (2013). The Asymmetric Commodity Inventory Effect on the Optimal Hedge Ratio. Journal of Futures Markets, 33(9), 868-888.

- Carpantier J-F \& Sapata C (2013). An Ex-post View of Inequality of Opportunity in France and its Regions. Journal of Labor Research, 34(3), 281-311.

- Chen T \& Tripathi G (2013). Testing Conditional Symmetry Without Smoothing. Journal of Nonparametric Statistics, 25, 273-313.

- de la Croix D, Pierrard 0 \& Sneessens H (2013). Aging and Pensions in General Equilibrium: Labour Market Imperfections Matter. Journal of Economic Dynamics \& Control, 37, 104-124.

- Dick J, Hussinger K, Blumberg B \& Hagedoorn J (2013). Is Success Hereditary? Evidence on the Performance of Spawned Ventures. Small Business Economics, 40 (4), 911-931.

- Dragone D, Lambertini L, Palestini A \& Tampieri A (2013). On the Optimal Number of Firms in the Commons: Cournot vs Bertrand. Mathematical Economics Letters, 1(1), 25-34.

- Goutte S \& Zou B (2013). Continuous Time Regime-switching Model Applied to Foreign Exchange Rate. Mathematical Finance Letters, 2013-8.

- Grimpe C \& Hussinger K (2013). Formal and Informal Technology Transfer from Academia to Industry: Complementarity Effects and Innovation Performance. Industry and Innovation, 20(8), 683-700.

- Han Y, Pieretti P \& Zou B (2013). An Extension of the Home-attachment Criteria Under Dynamic Tax Competition. Economics Letters, 121 (3), 508-510.

- Irmen A (2013). Adjustment Costs in a Variant of Uzawa's Steadystate Growth Theorem. Economics Bulletin, 33 (4), 2860-2873.

- Koulovatianos C, Antoniadou E \& Mirman L-J (2013). Strategic Exploitation of a Common-Property Resource under Uncertainty. Journal of Environmental Economics and Management, 65(1), 28-39.

- Lambertini L, Tampieri A \& Ecchia G (2013). Minimum Quality Standards in Hedonic Markets with Environmental Externalities. Environmental Modeling \& Assessment, 18(3), 319-323.

- Picard PM \& Tabuchi T (2013). On Microfoundations of the City. Journal of Economic Theory, 148(6), 2561-2582.

- Picard PM \& van Pottelsberghe de la Potterie B (2013). Patent Office Governance and Patent Examination Quality. Journal of Public Economics, 104(C), 14-25.

- Rovegno L (2013). Trade Protection and Market Power: Evidence from US Antidumping and Countervailing Duties. Review of World Economics, 149(3), 443-476.
- Severini T \& Tripathi G (2013). Semiparametric Efficiency Bounds for Microeconometric Models: A Survey. Foundations \& Trends in Econometrics, 6, 163-397.

- Vandenbussche H, Di Comite F, Rovegno L \& Viegelahn C (2013). Moving up the Quality Ladder? EU-China Trade Dynamics in Clothing. Journal of Economic Integration, 28(2), 303-326.

- Zanaj S, Gabszewicz J, Laussel D \& van Ypersele T (2013). Market Games in Successive Oligopolies. Journal of Public Economic Theory, 15(3), 397-410.

\section{Book Chapters}

- Cowan R, Jonard N \& Sanditov B (2013). Fits and Misfits: Technological Matching and R\&D Networks. In T Burger-Helmchen (Ed). The Economics of Creativity: Ideas, Firms and Markets, 281-308, Routledge.

\section{CREA Discussion Papers}

29 discussion papers were issued in 2013. All CREA Discussion Papers can be downloaded from our website.

(http://wwwfr.uni.lu/research/fdef/crea/publications2/

discussion_papers)

- 2013-01: Hamano M. The Consumption-real Exchange Rate Anomaly with Extensive Margins.

- 2013-02: Han Y, Pieretti, P \& Zou B. On the Desirability of Tax Coordination when Countries Compete in Taxes and Infrastructures.

- 2013-03: Picard PM \& Mossay P. Spatial Segregation and Urban Structure.

- 2013-04: Hamano M. Endogenous Firm Creation and Destruction over the Business Cycle.

- 2013-05: Vermeulen W. Resource Income and the Effect on Domestic Neighbours: A Case Study on Canadian.

- 2013-06: Zou B \& Herbert D. Strategies of Foreign Direct Investment in the Presence of Technological Spillovers.

- 2013-07: Carpantier J-F \& Dufays A. Commodities Inventory Effect.

- 2013-08 : Perego E \& Vermeulen W. Macroeconomic Determinants of European Stock and Government Bond Correlations: A Tale of Two Regions.

- 2013-09: Carpantier J-F, Bodart V \& Candelon B. Real Exchange Rates, Commodity Prices and Structural Factors in Developing Countries 
- 2013-10: Severini T \& Tripathi G. A Survey of Semiparametric Efficiency Bounds for Some Microeconometric Models.

- 2013-11 : Carpantier J-F \& Sapata C. Empirical Welfare Analysis When Preferences Matter.

- 2013-12: Gabszewicz J \& Zanaj S. (Un)stable Vertical Collusive Agreements.

- 2013-13: Zou B. Differential Game with (A)symmetric Players and Heterogeneous Strategies.

- 2013-14: Schumacher I \& Zou B. Threshold Preferences and the Environment.

- 2013-15: Han Y, Pieretti P \& Zou B. The Dynamics of the Location of Firms- A Revisit of Home-attachment under Tax Competition.

- 2013-16: Hubar S, Koulovatianos C \& Li J. Analytical Guidance for Fitting Parsimonious Household-Portfolio Models to Data.

- 2013-17: Heer B \& Irmen A. Population, Pensions, and Endogenous Economic Growth.

- 2013-18: Hamano M. Extensive and Intensive Margins and the Choice of Exchange Rate Regimes.

- 2013-19: Gabszewicz J, Tarola 0 \& Zanaj S. Migration, Wages and Fiscal competition.

- 2013-20: Thisse J, Pieretti P \& Zanaj S. Offshore Financial Centres: Tax Havens or Safe Havens.

- 2013-21: Hamano M. On Business Cycles of Variety and Quality.

- 2013-22: Carpantier J-F, Delvenne J-C \& Krings G. Trade Integration and Trade Imbalances in the European Union: A Network Perspective.

- 2013-23: Achury C, Koulovatianos C \& Tsoukalas J. Political Economics of External Sovereign Defaults.

- 2013-24: Han Y. Who Benefits from Partial Tax Coordination?

- 2013-25: Rovegno L. Endogenous Trade Restrictions and Exporters' Pricing Behaviour.

- 2013-26: Irmen A. A Generalized Steady-State Growth Theorem.

- 2013-27: Irmen A. Capital and Labour-Saving Technical Change in an Aging Economy.

- 2013-28: Tampieri A. Students Social Origins and Targeted Grade Inflation.

- 2013-29: Parilina E \& Tampieri A. Marriage Formation as an Optimal Stopping Problem with Assortative Meeting.

\section{Other Discussion Paper Series}

- Batyra A, de la Croix D, Pierrard O \& Sneessens H (2013). Declining Bargaining Power of Workers and the Rise of Early Retirement in Europe, Galatasaray University Economic Research Center, WP 13-06.

- Brueckner K, Lee DN, Picard PM \& Singer E (2013). Product Unbundling in the Travel Industry: The Economics of Airline Bag Fees, CESifo Working Paper Series 4397, CESifo Group Munich.

- El Joueidi S (2013). A Taxonomy of Manufacturing and Service Firms in Luxembourg According to Technological Skills, Economie et Statistiques, STATEC Working Papers, Luxembourg (also available as MPRA Paper 49532, University Library of Munich, Germany).

- Han Y, Pieretti P \& Zou B (2013). Does Size Asymmetry Exacerbate the Inefficiency of Tax Competition? Working Papers 486 , Bielefeld University, Centre for Mathematical Economics (forthcoming in Economics Letters).

- Heger D \& Hussinger K (2013). External Capital Access and New Product Launch in Start-up Firms with Uncertain Intellectual Property Rights, ZEW Discussion Papers 13-095, ZEW - Centre for European Economic Research, Mannheim.

- Hussinger K \& Schwiebacher F (2013). The Value of Disclosing IPR to Open Standard Setting Organisations, ZEW Discussion Papers 13-060, ZEW - Center for European Economic Research, Mannheim.

- Kammas P, Litina A \& Palivos T (2013). The Quality of Public Education in Unequal Societies: The Role of Tax Institutions, MPRA Paper 52193, University Library of Munich, Germany.

- Lambertini L \& Tampieri A (2013). Endogenous Timing in Quality Choices and Price Competition, Economics Discussion Papers 2013-37, Kiel Institute for the World Economy.

- Romano RE \& Tampieri A (2013). Arts vs Engineering: The Choice among Consumption and Investment in Education. WP892, Dipartimento Scienze Economiche, Universita' di Bologna. 


\section{PhD Dissertations}

- Rusli R (2013). Financing and Regulation for Developing Country Natural Resource and Energy Industries. Unpublished doctoral thesis, University of Luxembourg.

(Supervisor: Picard PM)

- Vermeulen W (2013). Essays on Dutch Disease and International Finance. Published doctoral thesis, University of Luxembourg. (Supervisor: Beine M) 


\section{Research Programmes}

International Migration Policy and Law Analysis (IMPALA)

Over the years, a variety of policies have been adopted by governments to regulate immigration. To empirically evaluate the merits of alternative policies, one needs appropriate data. Five universities (the universities of Amsterdam, Harvard, Luxembourg, Sydney and the London School of Economics) have decided to join efforts to build a comprehensive cross-national database. This multidisciplinary project, known as the "IMPALA - International Migration Policy and Law Analysis" project, will collect data on immigration laws and policies for 26 major recipient countries from 1960 to the present day. CREA's contribution to the project is supervised by Michel Beine and funded by a CORE- FNR grant.

\section{Diasporas and Network Effects}

E. Empirical Methods

The emphasis is on quantitative methods, combining theoretical models with numerical or empirical analyses to study the economic behaviour of individuals, organisations and geographical entities. The following sections give a brief description of the main ongoing research activities in each of these five areas.

\section{A. Regional Development and Globalisation}

The focus is on economic interactions between geographical entities (however large these may be defined) and the impact of these interactions on development opportunities. The ongoing "globalisation" process makes these questions most timely, especially (but not only) for a country like Luxembourg.

Many channels come into play and may involve tax competition effects, environmental constraints, knowledge spill overs, agglomeration effects, etc. Current research activities focus on the following channels: (i) mobility of workers and international migration, (ii) mobility of firms, (iii) trade and (iv) regional and urban interactions.

The faculty members involved in these research activities are: Michel Beine, Arnaud Bourgain, Patrice Pieretti, Pierre M Picard, Jacques Thisse, Skerdilajda Zanaj, Benteng Zou.

\section{(i) Mobility of Workers - International Migration}

The focus is on the causes, consequences and policy implications of the international mobility of workers. The issues that are covered are numerous, including: the selection of migrants, the factors determining international migration flows of workers and other categories of migrants such as students as well as the measurement and choice of migration policies etc.

Migrants' networks have been found to exert important economic effects. They favour the further migration of people and the movement of goods, capital and ideas across national borders. Michel Beine and Khalid Sekkat (University of Brussels) ${ }^{5}$ analyse the impact of migration networks on the transfer of ideas. More specifically, they examine two channels through which international migration may affect the evolution of the institutions in the origin countries. The first channel is the influence of emigration per se, i.e. people who left the country can voice more or less from abroad. The second channel is the transfer of the norms of the host country to the home country. The existence of both channels is confirmed using different indicators of institutional quality. The effects appear stronger when skilled emigration is considered.

Michel Beine, Frédéric Docquier (IRES ${ }^{6}$. Université catholique de Louvain) and Maurice Schiff (World Bank) ${ }^{7}$ focus on social norms and provide evidence of a significant transfer of destination countries' fertility norms from migrants to their country of origin: a $1 \%$ decrease (increase) in the fertility norm to which migrants are exposed reduces (raises) home country fertility by about $0.3 \%$.

The existing literature has already shown that network effects are an important determinant of migration flows, especially for women and less skilled workers. Michel Beine and Sara Salomone (IRES, Université catholique de Louvain $)^{8}$ deepen these analyses by simultaneously considering the gender and the educational dimensions. Using new data that include both dimensions, they analyse the respective impact that networks have on the proportion of each category of migrant. In contrast to the preceding body of literature on the macro determinants of international migration, they find that network effects vary by education level, but not by gender.

${ }^{5}$ Beine M \& Sekkat K (2013). Skilled Migration and the Transfer of Institutional Norms. IZA : Journal of Migration, 2(9), 2-19.

${ }^{6}$ Institut de Recherches Economiques et Sociales - Université catholique de Louvain. ${ }^{7}$ Beine M, Docquier F \& Schiff M (2013). International Migration, Transfer of Norms and Home Country Fertility. Canadian Journal of Economics, 46(4), 1406-1430.

${ }^{8}$ Beine M \& Salomone S (2013). Network Effect in International Migration: Does Education Matter More than Gender? Scandinavian Journal of Economics, 115(2), 354-380. 


\section{Migration Flows and Skill Distribution}

Permanent immigration can have major implications for the skill distribution of the labour force in the host country, as well as for the sustainability of the welfare state, especially public pension schemes. A team coordinated by Patrice Pieretti and Benteng Zou investigates these issues within an overlapping-generations model with endogenous educational and occupational choices. Immigration affects natives' educational decisions and thereby the skill distribution and the allocation of natives and migrants across sectors. The project is funded by the UL and developed with Luca Marchiori from the Banque Centrale du Luxembourg.

\section{Tax Competition and Labour Mobility}

It is often feared that international factor mobility combined with tax competition among countries might lead to a "race to the bottom": to avoid the exit of workers, governments would have to cut taxes and reduce the provision of public goods or welfare benefits. Recent advances in this field show however that this does not hold true in all circumstances, for instance when there is heterogeneity in sizes and productivity levels. Skerdilajda Zanaj with Jean Gabsewicz (CORE, Université catholique de Louvain) and Ornella Tarola (University of Rome "La Sapienza")9 examine the consequences of tax competition versus tax coordination. In particular, it is shown that being "small" can be an advantage only if there is no productivity handicap. In a recent work, Skerdilajda Zanaj and Jean Gabszewicz analyse the welfare effects of migration under flexible versus rigid labour markets. They show that, in most cases, migration is welfare detrimental for the destination country. ${ }^{10}$

\section{Sustainable Free Migration Policies}

Since the last economic recession, most EU countries have decreased their net immigration flows. While Spain has dramatically reduced its immigration after 2010 , Greece is now a country with net emigration. At the same time, many countries (e.g. the UK) respond to the recession by significantly strengthening their immigration and residence requirements. In this context, Pierre M Picard and Tim Worrall (University of Edinburgh) study the countries' incentives to adopt and maintain the European policy of free mobility of workers (Article 45 in the Lisbon Treaty). They develop a theoretical framework where the long run benefits of an open labour market are balanced with the short run cost of immigration.

\section{(ii) Mobility of Firms and Capital}

Several projects focus on the effects of fiscal and institutional competition on capital flows and firms' location choices. As for increased labour mobility, it is feared that increased capital mobility will lead to a "race to the bottom" and would undermine modern welfare states, unless some form of tax coordination is implemented. Ongoing research shows however that the merits of tax coordination cannot be evaluated without taking into account non-tax instruments and cross-country asymmetries.

\section{Tax Competition Revisited}

Many authors demonstrate that the tax gap resulting from tax competition increases with the size asymmetry of the competing countries. Consequently, increasing countrysize disparities exacerbates the inefficiency of tax competition. Yutao Han, Patrice Pieretti and Benteng Zou ${ }^{11}$ show however that this classical view is no longer valid when countries compete not only in taxes, but also in the provision of infrastructure. These infrastructures include the quality of the institutions and their impact on the firm's productive efficiency. The effect of size asymmetries on efficiency then depends crucially on the degree of international capital mobility. Patrice Pieretti and Skerdilajda Zanaj find ${ }^{12}$ that for moderate mobility costs small economies can attract foreign capital by supplying higher levels of productivity enhancing public goods, without having to rely on tax undercutting. The classical result that small jurisdictions are attractive because they engage in tax dumping is recovered only for high mobility costs of capital. Yutao Han, Patrice Pieretti and Benteng Zou ${ }^{13}$ further show that when jurisdictions compete in both taxes and infrastructures, coordination consisting of the imposition of a lower bound on tax rates increases only the revenue of the high tax country. When the jurisdictions decide to set a uniform tax rate, the profitability of coordination crucially depends on how asymmetric countries are.

Partial tax coordination is often regarded as a more realistic option than full tax coordination. Partial tax coordination is a situation where each individual agent cooperates only with a subset of the others. The Enhanced Cooperation Agreements among EU member states provide an example of partial coordination. The desirability of partial tax coordination is traditionally examined under the assumption that countries compete solely in taxes. Yutao $\mathrm{Han}^{14}$ re-examines this question by considering that countries may compete both in taxes and productive infrastructures. She demonstrates that a subgroup of countries agreeing on a common tax rate can harm both member and non-member states. This is in contrast to the classical findings that partial tax harmonisation is Pareto improving.

\footnotetext{
${ }^{9}$ Zanaj S, Tarola 0 \& Gaszewicz J (2013). Migration, Wages and Fiscal Competition. CREA Discussion Paper 2013-19.

${ }^{10}$ Zanaj S, Gaszewicz J (2014). Migration: A Burden or a Blessing for the Natives. CREA Discussion Paper 2014-01.

${ }^{11}$ Han Y, Pieretti P \& Zou B (2013). Does Size Asymmetry Exacerbate the Inefficiency of Tax Competition? Working Papers 486, Center for Mathematical Economics, Bielefeld University (forthcoming in Economics Letters).

${ }^{12}$ Pieretti P \& Zanaj S (2011). On Tax Competition, Public Goods Provision and Jurisdictions' Size. Journal of International Economics, 84, 124-130.

${ }^{13}$ Han Y, Pieretti P \& Zou B (2013). On the Desirability of Tax Coordination. CREA Discussion Paper 2013-02.

${ }^{14}$ Han Y (2013). Who Benefits from Partial Tax Coordination. CREA Discussion Paper 2013-24.
} 
Tax competition is also relevant in discussing territorial organisation. Marie-Laure Breuillé and Skerdilajda Zanaj ${ }^{15}$ analyse how the merger of regions affects capital tax competition in a two-tier territorial organisation where both regions and cities share the same mobile tax base. They identify three effects generated by the merger of regions that impact, directly or indirectly, both regional and local tax choices: (i) the alleviation of tax competition at the regional level, (ii) a scale effect in the provision of regional public goods, and (iii) a larger internalisation of vertical tax externalities generated by cities. They show that the merger of regions always increases regional tax rates while decreasing local tax rates.

\section{Offshore Financial Centres}

The previous insights are also useful to investigate the case of offshore financial centres. Most of the existing literature emphasises the negative impact of tax havens on the provision of public goods and their impact on illegal activities like money laundering. A project funded by the UL and led by Skerdilajda Zanaj together with Patrice Pieretti, Pierre M Picard and Jacques Thisse examines other channels through which tax evasion in offshore centres may affect the overall welfare of investors. The objective is to identify the optimal strategies that international banking centres should adopt to face the international pressure. In the wake of the financial crisis of 2008, an anti-evasion action was re-launched by the G-20, urging both OECD and non-OECD countries to sign "Tax Information Exchange Agreements" and putting offshore financial centres under pressure to abandon banking secrecy.

In this context, Pierre M Picard and Patrice Pieretti ${ }^{16}$ discussed the winners and losers of such policies and showed that they may increase aggregate profits and tax revenues, although their implementation on an onshore institution may be inefficient. Arnaud Bourgain, Patrice Pieretti and Skerdilajda Zanaj ${ }^{17}$ argued that tax planning strategies may undermine or at least reduce the benefits from removing banking secrecy and showed that solely targeting the abolition of banking secrecy may not be enough. Combating banking secrecy policy is a complex task that requires a clear understanding of modern offshore financial centres and their capacity to adapt their tax minimisation strategies to ever-changing regulatory environments.

In the same vein, a recent paper by Patrice Pieretti, Jacques Thisse and Skerdilajda Zanaj ${ }^{18}$ examines why and how a small country can become an offshore financial centre. They consider two countries, one small and the other large, competing for portfolio investments. The two countries compete with two instruments, taxation and institutional infrastructure. The conditions for an offshore financial centre to be a tax haven, a safe haven, or both, are identified. It turns out that the existence of a tax haven need not be as bad as usually claimed because its presence fosters institutional competition which is beneficial to all investors.

\section{Dynamic Foreign Investment Strategies}

Firms' location choices are not irreversible. In a globalised ever-changing world, foreign investment today may be followed by disinvestment tomorrow. Such reversals are not necessarily the consequence of initial misperceptions. They may rather be the result of a well-informed optimal dynamic strategy. To better understand such relocation choices, Patrice Pieretti, Benteng Zou and Yutao $\mathrm{Han}^{19}$ revisit the usual static home-attachment model and recast it in a dynamic setup which they next use to study the dynamics of tax and infrastructure competition.

Foreign investment dynamics also drive technological transfers. Firms with advanced technology are aware that their activities in foreign countries may help their foreign competitors to update their technologies. Whether there is full catch-up or not depends on the capacity of the competitor to absorb and exploit transferable knowledge. Benteng Zou ${ }^{20}$ and Herbert Dawid (University of Bielefeld) study these dynamic strategic interactions within a model where the absorption capacity of the foreign firm is endogenous and depends on its effort to catch up. They find that in some cases the high-tech outsourcing firm may be able to permanently maintain its technological advantage.

\section{(iii) Trade}

Unfair competition is a major concern in a globalised world. Contingent protection measures like antidumping (AD) and countervailing (CV) duties were originally intended to protect domestic producers from "unfairly" cheap imports. However, given the way in which these policies are designed and implemented, the trade literature tends to view them today mostly as industry-policy tools aimed at protecting domestic producers in the face of increasing import competition. Laura Rovegno ${ }^{21}$ contributes to this debate by studying the impact of US AD and CV duties on domestic producers' price-cost margins. She uses a long panel of 4-digit industries in the US covering 26 years of $A D / C V$ activity, including the periods before and after the changes to AD/CV laws introduced after the Uruguay Round. She finds a positive effect of AD/CV duties on price-cost margins for the period prior to the Uruguay Round, but the effect seems to disappear thereafter. In another piece of work

\footnotetext{
${ }^{15}$ Breuillé M-L \& Zanaj S (2013). Mergers in Fiscal Federalism. Journal of Public Economics, 105, 11-22 ${ }^{16}$ Picard PM and Pieretti P (2011). Bank Secrecy, Illicit Money and Offshore Financial Centers, Journal of Public Economics, 95 (7-8), 942-955.

${ }^{17}$ Bourgain A. Pieretti P \& Zanaj S (2012). From Tax Evasion to Tax Planning. CREA Discussion Paper 2012-16.

${ }^{18}$ Pieretti P. Thisse J, Zanaj S (2013). Offshore Financial Centres - Safe or Tax Havens. CREA Discussion Paper 2013-20.

${ }^{19} \mathrm{Han}$ Y. Pieretti P \& Zou B. (2013). An Extension of the Home-Attachment Criteria under Dynamic Tax Competition, Economics Letters, 83(3), 347-353.

${ }^{20}$ Dawid H \& Zou B (2013). Strategies of Foreign Direct Investment in the Presence of Technological Spillovers. CREA Discussion Paper 2013-06.

${ }^{21}$ Rovegno L (2013). Trade Protection and Market Power: Evidence from US Antidumping and

Countervailing Duties. Review of World Economics, 149(3), 443-476.
} 
on these issues, Laura Rovegno ${ }^{22}$ uses product and firm-level data for South Korea to study the impact of $A D$ duties on the pricing behaviour of exporters targeted by these measures. Her study suggests that the imposition of $A D$ ad valorem duties led to increases in export unit values and in firms' mark-ups. These findings are consistent with the hypothesis that, unlike other import tariffs, $A D$ duties are not absorbed by exporters. The results on firms' average mark-ups also suggest that the price adjustment following the imposition of $A D$ duties occurs mostly through the export price, and not through reductions in the exporter's home price.

Another concern is the quality of cheap imports. Laura Rovegno with co-authors from the Université catholique de Louvain ${ }^{23}$ study the relative quality of Chinese versus European products exported in the clothing sector after the end of the Multi-fiber Arrangement. Using UN Comtrade data, they find that European varieties exported to the US typically sell for a higher price than identical Chinese varieties exported to the US, but this price gap is narrowing. Despite rising prices, Chinese varieties are gaining market share. This opposite movement of relative prices and quantities sold in the same destination market are a strong indication that China is moving up the quality ladder in its clothing exports relative to the EU.

Trade relationships between European countries are ever more integrated and at the same time ever more unbalanced. JeanFrançois Carpantier with Gautier Krings and Jean-Charles Delvenne (ICTEAM ${ }^{24}$, Université catholique de Louvain $)^{25}$ proposes two global measures to assess the trade integration and the trade imbalances of the European countries. These measures are the network (indirect) counterparts to traditional (direct) measures like the trade-to-GDP and trade deficit-to-GDP ratios. The indirect tools account for the European inter-country trade structure and follow (i) a decomposition of the global trade flow into elementary flows that highlight the long-range dependencies between exporting and importing economies and, (ii) the commute-time distance for trade integration, which measures the impact of a perturbation in the economy of a country on another country, possibly through intermediate partners by domino effect. These measures are next used to examine the impact of the launch of the Euro.

\section{(iv) Regional and Urban Interactions}

\section{Economic Geography and Product Quality}

This project led by Pierre M Picard studies the impact of trade cost on the location of economic activities and of capital under product quality heterogeneity. The focus is on the role of product quality in international trade, and the understanding and measuring of the geographical clustering of production of higher quality goods and services in specific geographical areas. The objective is to check the claim that firms selling the higher quality goods select the region hosting the largest number of consumers, and the claim that larger regions get better access to the higher quality products. This study will help understand how the spatial distribution of firms depends on the number and the quality of varieties, and whether the introduction of product quality heterogeneity leads to smoother agglomeration patterns than those predicted by the standard economic geography framework. The project involves two Post-docs, Masashige Hamano and Ha Man N'Guyen, and is developed in collaboration with the University of Kobe, University of Quebec (Montreal) and University of Singapore. It also benefits from the funding support of the FNR (National Research Fund of Luxembourg) and the University of Luxembourg.

\section{Urban Economics}

Pierre M Picard supervises a project devoted to the study of the factors explaining the structure of cities. It focuses on the microeconomic foundation of cities and on the existence and efficiency of sprawl and multiple centres in cities. It also studies the impact of urban transport systems. The project is funded by the UL and is developed in collaboration with the University of Reading, University of Tokyo, University Carlos III, and University of California Irvine.

It has been shown empirically that a region that hosts a large city strongly contributes to the market potential for its own firms. This empirical observation suggests that trade linkages can be important agglomeration drivers and may play an important role in shaping the structure of cities. Pierre M Picard and Takatoshi Tabuchi (University of Tokyo) ${ }^{26}$ investigate this issue and provide the first formal model of urban spatial structure based on a microeconomic foundation of demand and supply linkages as it has been discussed in the framework of new economic geography. They disentangle the impact of supply linkages from final demand linkages and show that both effects foster the concentration of firms and raise urban land rents.

A paper by Pierre M Picard and Pascal Mossay (University of Reading $)^{27}$ focuses on spatial segregation and concentration. In many cities population groups are sorted into distinct spatial neighbourhoods. For most observers, the main reason for such spatial segregation lies in the economic ties and social interactions that people have with individuals of their reference group. The prevalence of segregation is exacerbated by poverty as poor people are more likely to see their economic prospects and social relationships improved within their own ethnic group. Spatial concentration also affects business and professional activities. In this perspective, the research question is how social interactions may

\footnotetext{
${ }^{22}$ Rovegno L (2013). Endogenous Trade Restrictions and Exporters' Pricing Behaviour. CREA Discussion Paper 2013-25.

${ }^{23}$ Vandenbussche H, Di Comite F. Rovegno L \& Viegelahn C (2013). Moving up the Quality Ladder? EU-China Trade Dynamics in Clothing. Journal of Economic Integration, 28(2), 303-326. ${ }^{24}$ Institute of Information and Communication Technologies, Electronics and Applied Mathematics, Université catholique de Louvain

${ }^{25}$ Krings G. Carpantier J-F, Delvenne J-C (2013). Trade Integration and Trade Imbalances. CREA Discussion Paper 2013-22.

${ }^{26}$ Picard PM \& Tabuchi T (2013). On Microfoundations of the City. Journal of Economic Theory. 148(6), 2561-2582.

${ }_{27}^{27}$ Picard PM and Mossay P (2013). Spatial Segregation and Urban Structure. CREA Discussion Paper 2013-03.
} 
lead to spatial segregation and how these interactions structure urban neighbourhoods. Though segregation is a common result in the urban literature, this study is the first attempt to deal with the issue without assuming the exogenous existence of a central place. It is shown that integration is never a spatial equilibrium. Spatial structures will instead involve segregation into two or three urban districts. Depending on the parameters, various urban structures can coexist. This study helps understand how city growth may affect urban structures. It also sheds some light on the impact of social integration programmes on urban structures.

\section{The EU in the New Complex Geography of Economic Systems}

Spatial inequalities are evolving through time along complex patterns determined by economic, geographical, institutional and social factors. Such inequalities represent a big challenge for policymakers. A COST ${ }^{28}$ project has been set up with the objective of developing a suitable methodology to deal with these questions. This interdisciplinary-interuniversity project is led by Pasquale Commendatore (Univiversity di Napoli) and Ingrid Kubin (WU Vienna University of Economics and Business) and supervised on the UL side by Benteng Zou. The proposed approach goes beyond the usual New Economic Geography model and sees the EU as an evolving trade network with a specific topology determined by the number and strength of national, regional and local links. It combines recent approaches in economics with the most advanced mathematical and computational methods for analysing complex and non-linear systems. This research should provide a basis for an improved evaluation of policies like the European cohesion policy.

\section{B. Macroeconomics and Growth}

This research area focuses on the determinants of economic fluctuations and growth. Examples of timely issues are environmental factors, labour market policies, technical change, demographics, the role of capital movements, of financial markets and macro prudential rules. A major objective is the development of theoretical and empirical foundations for economic policy.

Current research activities focus on the following issues: the macroeconomic impact of demographic changes, the causes and consequences of technical change, sustainable development, economic fluctuations, financial markets and economic policy.

The faculty members involved in these research activities are Michel Beine, Luisito Bertinelli, Arnaud Bourgain, Andreas Irmen, Christos Koulovatianos, Pierre M Picard, Henri Sneessens, Benteng Zou.

\section{(i) Sustainable Development}

This area of research is devoted to the macroeconomic and environmental performance of nations. The focus is on the factors that make growth sustainable in the long run.

\section{Capital vs Labour-augmenting Progress}

Andreas Irmen generalises Uzawa's Steady-state Growth Theorem in two ways. First, he shows ${ }^{29}$ that there is room for steady state capital-augmenting technical progress in the presence of adjustment costs associated with the installation of new capital. This is in sharp contrast to Uzawa's original finding. Second, he develops an extension of Uzawa's Steady-state Growth Theorem that applies when capital and labour-augmenting technical progress is endogenous. He shows that even if the direction of technical change can be chosen by entrepreneurs the steady state has only labour-augmenting technical change. ${ }^{30}$ Andreas Irmen's theorem provides a theoretical underpinning for much of the modern literature on endogenous technical change and its direction.

\section{Demographics, Economic Growth and World Income Distribution}

Population aging is one of the major economic challenges for today's industrialised societies. An increasing life expectancy in conjunction with declining birth rates tends to reduce the part of the population in working age and raises the part of the economically dependent old. Ongoing research led by Andreas Irmen with Anastasia Litina (Post-doc) and Amer Tabakovic (PhD) focuses on the relationship between population aging and economic growth, issues of pension reform in aging economies, the role of aging for the life-cycle earnings distribution, fundamental explanations of the world income distribution of today, institutional and cultural explanations of economic growth, development of a task-based approach to study the causes and the consequences of endogenous economic growth.

With Burkhard Heer (University of Augsburg), Andreas Irmen ${ }^{31}$ studies the effect of a declining labour force on the incentives to engage in labour-saving technical change and asks how this effect is influenced by institutional characteristics of the pension scheme. When labour is scarcer, it becomes more expensive and innovation investments that increase labour productivity are more profitable. They calibrate an intertemporal general equilibrium model with overlapping generations for the US economy and obtain that the effect of a decline in population growth on labour produc-

\footnotetext{
${ }^{28}$ European Cooperation in Science and Technology is one of the longest-running European frameworks supporting cooperation among scientists and researchers across Europe. ${ }^{29}$ Irmen A (2013). Adjustment Costs in a Variant of Uzawa's Steady-state Growth Theorem. Economics Bulletin.

${ }^{30}$ Irmen A (2013). A Generalized Steady-State Growth Theorem. CREA Discussion Paper 2013-26. ${ }^{31}$ Heer B and Irmen A (2013). Population, Pensions and Endogenous Economic Growth. CREA Discussion Paper 2013-17.
} 
tivity growth is positive and quantitatively significant. Institutional characteristics of the pension system matter both for the growth performance and for individual welfare. One implication of this work is that a correct assessment of pension reform proposals should take into account the endogenous nature of economic growth.

To further investigate this point, Andreas Irmen ${ }^{32}$ develops a novel analytical framework that allows for population aging to affect endogenous capital and labour-saving technical change. The shortrun analysis reveals that population aging induces more labour-saving and less capital-saving technical change as it increases the relative scarcity of labour with respect to capital. Due to external contemporaneous knowledge spillovers across innovating firms, induced technical change has a first order effect on current aggregate income. In the long-run capital-saving technical progress vanishes, and the economy's growth rate reflects only labour-saving technical change. However, the mere possibility of capital-saving technical change is shown to imply that the economy's SteadyState Growth Rate becomes independent of its age structure: neither a higher life-expectancy nor a decline in fertility affects economic growth in the long run.

\section{Pollution Mitigation and Sustainable Development}

Pollution mitigation can be obtained either via abatement or via the adoption of cleaner technologies, or both. Adopting clean technologies is a long term process which requires structural changes in the production and consumption habits, while pollution abatement is typically a short term objective. Both aspects are considered in the projects supervised by Luisito Bertinelli and Benteng Zou. Part of this research has been funded by the University of Luxembourg.

The question of the adoption of clean technologies is examined in terms of the strategic behaviours of different countries or regions facing trans-boundary carbon dioxide emissions. The reduction of carbon dioxide concentration occurs through the carbon capture and storage process. The potential role of carbon capture and storage technologies is assessed in light of (i) uncertainties that this technology involves, and (ii) strategic interactions that may arise among adopting countries.

Studying these questions raises a number of methodological issues. Public opinion, which has a substantial impact on governments' choices and decisions, tends to be sticky and changes only when sufficiently pressing problems have been identified. Once this happens, it produces radical changes in preferences and government actions. To study the impact of such discrete changes in preferences on the trade-off between consumption and the environment, Ingmar Schumacher (IPAG Business School, Paris) and Benteng Zou ${ }^{33}$ introduce the idea of threshold preferences. They obtain that the location of the threshold determines both the potential steady states as well as the dynamics. For low (high) thresholds, environmental quality converges to a low (high) Steady State. For intermediate levels it converges to a stable p-cycle, with environmental quality being asymptotically bounded below and above by the low and high Steady State. These results have implications for intergenerational equity and policy making.

The study of trans-boundary pollution problems calls for methods that can take into account asymmetric strategies. In the framework of the Kyoto Protocol for instance, some countries like the EU take commitments about emission reductions from which they cannot deviate. Other countries, like the USA and China, do not commit to fixed objectives but rather regularly revise their targets and policies. Benteng Zou ${ }^{34}$ examines the dynamics of such heterogeneous strategies by the means of differential games.

\section{Climatic Impact on Socio-economic Development}

The consequences of climate on social and economic factors are polymorphous. This research focuses on two specific aspects, namely the consequences of extreme climate factors (i.e. natural hazards) on economic performance and the long term consequences of climate variability on societal choices. The project is led by Luisito Bertinelli, in collaboration with Eric Strobl (Ecole Polytechnique, Paris), Luca Marchiori (Banque Centrale du Luxembourg) and Jean-François Maystadt (LICOS ${ }^{35}$ KU Leuven and International Food Policy Research Institute, Washington DC).

In a study of the impact of hurricanes on economic activity Luisito Bertinelli and Eric Strobl (Ecole Polytechnique, Paris) ${ }^{36}$ use nightlight satellite imagery as a measure of local economic activity in conjunction with a local proxy for potential hurricane destruction generated from a wind field model to statistically assess the impact of hurricane strikes on local economic growth. This allows them to circumvent the standard approach in this literature, typically restricting data to a very aggregate level of analysis because of the lack of spatially disaggregated data. The regression results suggest that on average hurricane strikes reduce income growth by around $1.5 \%$ at the local level, with no effect beyond the year of the strike. This estimated impact from localised data is more than twice as large as that implied by aggregate analyses This study has been published in a journal of the American Meteorological Society.

In a further study, the same authors explore the impact of local pollutants (and in particular tropospheric ozone) on child mortality, by generalising the quasi-experimental approaches that have been recently used in the area. In particular, mechanisms of the atmospheric chemistry are used to develop an appropriate instrument. Unlike standard quasi-experimental approaches, results provide a method, generally applicable in space and time.

\footnotetext{
${ }^{32}$ Irmen A (2013). Capital- and Labour-Saving Technical Change in an Aging Economy. CREA Discussion Paper 2013-27.

${ }^{33}$ Schumacher I, Zou B (2013). Threshold Preferences and the Environment. CREA Discussion Paper 2013-14.

${ }^{34}$ Zou B (2013). Differential Game with (A)symmetric Players. CREA Discussion Paper 2013-13. ${ }^{35}$ Centre for Institutions and Economic Performance, KU Leuven.

${ }^{36}$ Bertinelli L \& Strobl E (2013). Quantifying the Local Economic Growth Impact of Hurricane Strikes: An Analysis from Outer Space for the Caribbean. Journal of Applied Meteorology \& Climatology, 52(8), 1688-1697.
} 


\section{Strategic Exploitation of a Common Natural Resource}

A well-known result in economic literature states that when there is a common natural resource to be shared by non-cooperating players, the outcome will be a lower level of this resource in the long run. The higher the number of non-cooperating players, the higher the aggregate exploitation rate, so the lower the level of the resource in the long run. This is the so-called "commons problem". This result is obtained in purely deterministic setups. Christos Koulovatianos ${ }^{37}$ with Eleni Antoniadou (Nottingham School of Economics) and Leonard Jay Mirman (University of Virginia) examines how non-cooperative strategic interaction is affected by uncertainty in the natural law of resource reproduction. They show that the commons problem is always present and identify cases in which increases in risk amplify or mitigate the commons problem.

\section{(ii) Financial Markets and the Macroeconomy}

The recent crisis is a clear illustration of the impact that financial markets and financial behaviours may have on the real economy and conversely. CREA PhDs Erica Perego and Wessel Vermeulen ${ }^{38}$ have used data from Euro zone core and periphery countries to investigate the effects of the crisis on the financial markets. They obtain striking evidence of a "financial disintegration" effect on bond markets, although not on stock markets. They also obtain evidence that these changes on the financial markets are connected to changes in economic variables like current account imbalances and public debt dynamics.

Christos Koulovatianos ${ }^{39}$ with Carolina Achury (Exeter School of Business) and John Tsoukalas (University of Glasgow) have studied which economic fundamentals make partisan cooperation possible and politically sustainable. The context is the formation of coalition governments or partisan cooperation in countries where solving the sovereign debt crisis calls for programmes of controlled fiscal spending. Specifically, they examine whether quotas on fiscal debt-GDP ratios (as used in the Maastricht criteria) guarantee the political feasibility of fiscal prudence once a country is already member of a monetary union. Their results suggest that debt-GDP ratios below $137 \%$ foster cooperation among rent-seeking groups, which avoids collective fiscal impatience and default.

Many observed financial behaviours remain actually poorly understood. It is observed for instance that saving rates and household investment in stocks and business equity are all increasing in income and wealth. These monotonic relationships can hardly be explained through standard portfolio-choice/ savings-consumption models. Using the simplest possible model with labour-income risk that adheres to the Permanent-income Hypothesis, Christos Koulovatianos ${ }^{40}$ with Sylwia Hubar (Exeter School of Business) and Jian Li (Goethe University, Frankfurt) demonstrate the crucial role played by subsistence consumption in reconciling the model with observed stylised facts. It is found in that context that poorer households can afford exiting subsistence concerns slowly by saving less and by taking less risk, while holding balanced portfolios.

\section{(iii) Open Economy Macroeconomics}

The exchange rate is a crucial variable for open economies. Depending on the nature of the disturbance hitting the economy (for instance financial vs real disturbance) and the characteristics of that economy, a change in the exchange rate may be desirable or not.

\section{Fixed vs Flexible Exchange Rates}

Whether a fixed exchange rate regime is superior to a flexible regime will depend on the ability of the economy to absorb the shocks without an exchange rate adjustment. This is precisely the question investigated by Pierre M Picard and Masashige Hamano (Post-doc)..$^{41}$ More specifically, they study the role of adjustments along the extensive (entry/exit of firms) vs intensive (expansion/ contraction of firms) margins of production in the face of demand (preference) shocks. They consider an economy with short run nominal rigidities. They show that fixed exchange rate regimes are preferred when entry occurs at the same time as production in each period and when labour supply elasticities are large; they are less attractive in the presence of production lags and higher love of product diversity. Their project also aims at investigating whether a currency area is more prone to develop fiscal transfers and a common fiscal system between its member states.

\section{The Backus-Smith Puzzle}

Exchange rate fluctuations have implications for consumption growth. Perfect international risk sharing under complete asset markets would imply that consumption in one country rises when its prices become relatively cheaper. Such a pattern of consumption growth and real exchange rate fluctuations, however, is strongly rejected by data. This pattern, known as the Backus-Smith Puzzle, is even more surprising given the rise in international capital flows and the progressive integration of world financial markets. Masashige Hamano ${ }^{42}$ presents a possible resolution of the puzzle based on three elements: (i) a wealth effect due to changes in the number of product varieties; (ii) statistical inefficiency in measuring the number of product varieties; and (iii) market incompleteness.

\footnotetext{
${ }^{7}$ Koulovatianos C, Antoniadou E \& Mirman L-J (2013). Strategic Exploitation of a Common-Property Resource under Uncertainty. Journal of Environmental Economics and Management, 65(1), 28-39. ${ }^{38}$ Perego E, Vermeulen W (2013). Macroeconomic Determinants of European Stock and Government Bond Correlations - A tale of Two Regions. CREA Discussion Paper 2013-08

${ }^{39}$ Achury C, Koulovatianos C \& Tsoukalas J ( 2013). Political Economics of External Sovereign Defaults CREA Discussion Paper 2013-23.

${ }^{40}$ Hubar S, Koulovatianos C \& Li J (2013). Analytical Guidance for Fitting Parsimonious Household-Portfolio Models to Data. CREA Discussion Paper 2013-16.

${ }^{41}$ Hamano M, Picard PM (2013). Extensive and Intensive Margins and the Choice of Exchange Rate Regimes. CREA Discussion Paper 2013-18.

${ }^{42}$ Hamano M (2013).The Consumption-real Exchange Rate Anomaly with Extensive Margins. CREA Discussion Paper 2013-01.
} 


\section{Dutch Disease Effects in Canadian Provinces}

Economic literature has emphasised the so-called Dutch Disease Effects, whereby the development of the natural resource sector induces exchange rate and demand adjustments that are detrimental to the other sectors of the country. Wessel Vermeulen $(\mathrm{PhD})^{43}$ focuses instead on the geographical dimension. When resources are concentrated in a given geographic region of the country, the neighbouring region will suffer from the country's real exchange rate appreciation but at the same time will benefit from the increased demand coming from the resource-rich neighbour. The analysis is based on a 2-region 2-sector model with inter-regional trade. The model is tested on a panel dataset of Canadian provinces. The panel estimations support the theoretical model and show that a province's resource production affects its neighbours in several ways. Their exports do not only affect their neighbours through the appreciation of the exchange rate as found previously, but also through a change in the interprovincial trade pattern. $A$ trade surplus that a resource exporting province established with the export of resources to the rest of the world is spend on a trade deficit with its closest trade partners, its neighbouring provinces. This demand for additional export goods is sizeable enough to have a statistically and economically significant effect in terms of sector sizes in both provinces that have themselves resource exports and those that do not.

\section{Real Exchange Rates Determinants}

Exchange rate movements are very hard to predict. The vast literature on this topic merely agrees on the fact that purely statistical models are superior to more ambitious approaches based on theory-based structural models when it comes to forecasting. The difficulty with predicting exchange rates is similar in that respect to the one encountered with many other financial variables. Benteng Zou ${ }^{44}$ with Stéphane Goutte (CNRS ${ }^{45}$. Université de Paris 7) proposes a new continuous time regime-switching model that can be used to study daily exchange rate movements. The regime switches are meant to capture changes in the macroeconomic environment. It is shown that allowing for several regimes significantly improves the performance of the model; in most cases, there is no need to have more than two regimes.

The connection between real exchange rates and the price of primary commodities is vital for many developing countries. Commodity price shocks will have important economic implications, mainly through their impact on the real exchange rate, as in the "Dutch Disease" model. Two pieces of work by Jean-François Carpantier (Post-doc) give new insights on this question. With Arnaud Dufays (CORE, Université catholique de Louvain), he shows ${ }^{46}$ that the volatility of commodity prices increases when inventories are low. Next, with Vincent Bodart (IRES, Université catholique de Louvain) and Bertrand Candelon (University of Maastricht), he shows ${ }^{47}$ that the long run response of real exchange rates to commodity price disturbances varies with the exchange rate regime, the degree of trade openness, the degree of export diversification and the type of the primary commodity that is exported. The degree of financial openness does not seem to have an effect. This inference is based a panel data set of 33 small developing countries over the period 1980-2007.

\section{(iv) Short-Run Macroeconomics}

Short-run macroeconomic models focus on the determinants of equilibrium unemployment and on the mechanisms that propagate the effects of exogenous shocks throughout the economy.

Masashige Hamano ${ }^{48}$ studies the business cycle properties of a dynamic stochastic general equilibrium (DSGE) model with monopolistic competition and Schumpeterian destruction. Firms enter the market through a free entry condition and exit endogenously depending on their specific productivity level. The model can replicate observed business cycle patterns for creation and destruction and other major economic variables. It has properties typical of a Schumpeterian economy. A recession for instance generates a "cleansing effect" and reallocates resources towards the most efficient firms. In contrast, there is "sclerosis effect", i.e. the survival of production units that would not survive in an efficient equilibrium in the non-Schumpeterian economy.

Masashige Hamano ${ }^{49}$ also explores the role played by product variety and quality over the business cycle. Firms are heterogeneous in terms of their specific quality as well as productivity levels. Firms which have costly technology enter in a period of high aggregated demand and produce high quality goods. Thus, the average quality level and number of available varieties are pro-cyclical, as in the data. The model can replicate the observed inflationary bias in the conventional consumer price index due to a rise in the number of new product varieties and quality.

Luisito Bertinelli ${ }^{50}$, with Olivier Cardi (University of Paris 2) and Partha Sen (Delhi School of Economics) uses a dynamic general equilibrium model with endogenous mark-ups and labour market frictions to investigate the effects of increased product market competition on equilibrium unemployment. Unlike most macroeconomic models of search, they allow for endogenous participation rates. It is shown that allowing for participation rate responses significantly reinforces the positive impact of product market deregulation on employment. A sensitivity analysis reveals that

\footnotetext{
${ }^{43}$ Vermeulen W (2013). Resource Income and the Effect on Domestic Neighbours - A Case Study on Canadian Provinces. CREA Discussion Paper 2013-05.

${ }^{44}$ Goutte S \& Zou B (2013). Continuous Time Regime-Switching Model Applied to Foreign Exchange Rate. Mathematical Finance Letters, 2013-8.

${ }^{45}$ Centre national de la Recherche scientifique, France.

${ }^{46}$ Carpantier J-F, Dufays A (2013).Commodities Inventory Effect. CREA Discussion Paper 2013-07.

${ }^{47}$ Bodart V. Candelon B, Carpantier J-F (2013).Real Exchange Rates, Commodities Prices and

Structural Factors in Developing Countries. CREA Discussion Paper 2013-09.

${ }^{48} \mathrm{Hamano}$ M (2013). Endogenous Firm Creation and Destruction Over the Business Cycle. CREA Discussion Paper 2013-04.

${ }^{49}$ Hamano M (2013). On Business Cycles of Variety and Quality. CREA Discussion Paper 2013-21. ${ }^{50}$ Bertinelli L, Cardi O \& Sen P (2013). Deregulation Shock in Product Market and Unemployment. Journal of Economic Dynamics \& Control, 37(4), 711-734.
} 
product market deregulation is more effective in countries where product and labour market regulations are high, unemployment benefits are small and the labour force is more responsive.

Henri Sneessens, with Olivier Pierrard (Banque Centrale du Luxembourg) and David de la Croix (IRES \& CORE, Université catholique de Louvain $)^{51}$ re-examines the effects of population aging and pension reforms in a general equilibrium model with overlapping generations and labour market frictions. The most important feature brought about by labour market frictions is the connection between population aging and the unemployment rate via the interest rate. Exogenous shocks (such as aging) leading to lower interest rates imply lower equilibrium unemployment rates, because lower capital costs stimulate labour demand and induce firms to advertise more vacancies. These effects may be reinforced by increases in the participation rate of older workers induced by higher wage rates and the larger probability of finding a job. These results imply that neglecting labour market frictions and employment rate changes may seriously bias the evaluation of pension reforms when they have an impact on the equilibrium interest rate. This analysis is further extended with Luca Marchiori (Banque Centrale du Luxembourg) to include the effects of capital flows.

\section{Strategic Interactions and Organisations}

The analysis of strategic behaviours encompasses both economics and management questions. It is the theoretical framework needed to evaluate the impact of industry regulations on competitiveness. It is also appropriate to examine strategic interactions between firms and their impact on innovation and management practices.

The faculty members involved in these research activities are: Matthias Brauer, Denise E Fletcher, Katrin Hussinger, Nicolas Jonard, Pierre M Picard, Virginie Terraza, Jacques Thisse and Skerdilajda Zanaj.

\section{(i) Industrial Organisation}

Market imperfections may lead to inefficient outcomes. One objective of public policy in this context is to impose regulations apt to ensure a proper functioning of markets. This calls for a better understanding of strategic behaviours in specific environments.

\section{Airline and Airport Industry}

The project aims at a better understanding of the economic factors sustaining collusion in the airline industry and the management of environmental externalities around airports. It is supervised by Pierre M Picard and includes collaboration with the
Université catholique de Louvain and the University of California, Irvine. The project benefits from the financial support of the FNR.

International air alliances may have both positive and negative effects for consumers. It is positive for long distance passengers who have easier and cheaper access to interline trips. It may however generate collusion harmful to hub-to-hub passengers. This concern motivated the introduction of regulatory "carve-outs" to maintain the pre-alliance competitive situation in the inter-hub market. The usefulness of such carve-outs still remains a much debated issue. Jan Brueckner (University of California, Irvine) and Pierre M Picard ${ }^{52}$ show that the gains from economies of density due to higher interline traffic under the alliance strengthen the incentive to collude on the inter-hub route, while the accompanying revenue gain heightens the incentive to defect from collusive behaviour. These two effects exactly cancel in the case of linear demand and linear economies of density. Under this approximation, the incentives for inter-hub collusion are no different before and after the formation of an airline alliance subject to a carve-out.

\section{Privatisation and Public-Private Partnership}

This project studies the role of information on the choice of privatisation of public firms. It analyses the cost and benefit of public-private partnerships (PPP). The project is led by Pierre M Picard and involves two PhD researchers, Ridwan Rusli and Xi Wan. It benefits from the support of FNR.

In the last two decades, many governments have increased their reliance on PPP to finance the acquisition of infrastructure assets and the operation of their facilities. A frequent form of PPP is the build-operate-transfer (BOT) concession under which the private sector builds and operates an infrastructure project for a well-defined concession period and then transfers it to public authorities. Emmanuelle Auriol (Toulouse School of Economics) and Pierre M Picard ${ }^{53}$ show that larger shadow costs of public funds and larger information asymmetries entice governments to choose BOT concessions. This result stems from a trade-off between the government's shadow costs of financing the construction and the operation of the facility and the excessive usage price that the consumer may face during the concession period. The incentives to choose BOT concessions increase as a function of informational asymmetries between governments and potential BOT concession holders and with the possibility of transferring the concession project characteristics to the public authority at the termination of the concession.

\footnotetext{
${ }^{51}$ de la Croix D, Pierrard 0 \& Sneessens H (2013). Aging and Pensions in General Equilibrium: Labour Market Imperfections Matter. Journal of Economic Dynamics \& Control, 37, 104-124. ${ }^{52}$ Brueckner J \& Picard PM (2013). Airline Alliances, Carve-Outs and Collusion. Review of Network Economics, 12(2), 211

${ }^{53}$ Auriol E \& Picard PM (2013). A Theory of BOT Concession Contracts. Journal of Economic Behavior \& Organization, 89, 187-209.
} 


\section{Successive Markets}

Skerdilajda Zanaj with Jean Gabszewicz (CORE, Université catholique de Louvain), Didier Laussel and Tanguy van Ypersele (Université d'Aix-Marseille), ${ }^{54}$ introduces an alternative approach to examine how successive markets operate when downstream firms cannot be assumed price takers in the input market (assumption made in the classical approach). This alternative approach relies on the notion of strategic market game. A natural question to ask in the setup of successive markets is the stability of vertical collusive agreements. Jean Gabszewicz and Skerdilajda Zanaj ${ }^{55}$ extend the concept of stability to collusive agreements involving downstream and upstream firms. They show that stable vertical collusive agreements exist even for market structures in which horizontal cartels would be unstable.

\section{(ii) Knowledge Production and}

\section{Intellectual Property Rights}

Innovation is considered as one of the most important drivers for the competitiveness and profitability of incumbent firms. Several projects aim at identifying the factors that contribute to research and innovation, and their implementation at the firm level.

\section{Patent Office Governance}

The constant growth in patent filings and the consequent backlogs have drawn the attention of many observers on the nature and the cost of the patent examination process. The question is of particular interest as two of the largest patent offices in the world, namely the US Patent and Trademark Office and the European Patent Office, have adopted opposite strategies. In the former the examination process is cheap and fast, with a low-to-medium relative quality of the examination process, whereas in the latter the examination is slower and more expensive, with a medium-to-high quality. Pierre M Picard and Bruno van Pottelsberghe de la Potterie (CORE and $\left.U_{L B}{ }^{56}\right)^{57}$ discuss the role of quality in patent examination process from the perspective of patent offices' behaviour and organisation. A higher effort in the examination process enhances the patent holders' protection in the judicial system and strengthens the screening of innovations with small inventive steps. Patent examination quality is the highest in an office maximizing incentives to innovate and the lowest in that maximizing the number of granted patents. A rent-seeking patent office can provide good incentives to innovate if it does not set too high mark-ups on fees.

\section{The Role of Intellectual Property Rights in Mergers \& Acquisitions (M\&As)}

Extant literature holds that firm acquisitions create value through innovation if the knowledge bases of the acquirer and the target complement each other. Little is known about the value that pat- ents associated with a target's knowledge convey to the acquirer, i.e., their value in securing market exclusion and freedom to operate in R\&D. Katrin Hussinger and Christoph Grimpe (Copenhagen Business School) ${ }^{58}$ argue that such property rights hold pre-emptive power allowing firms to capture the value from combining complementary technologies and to realise gains from trade in strategic factor markets. They find for a sample of 1,428 acquisitions that acquired pre-emptive power is an important determinant of the acquisition price, particularly when the acquirer is technology intensive and acquired patents are highly related to the acquirer's knowledge base.

Property rights can play also an important role in motivating researchers within universities. The academic and policy literatures express concerns about university research "privatisation" and its influence on knowledge disclosure and technology transfer. A project led by Katrin Hussinger ${ }^{59}$ in collaboration with KU Leuven, USDA Washington and ZEW Mannheim aims at exploiting a natural experiment to identify the causal effects of transferring patent rights from the individual researcher to the university where he/ she is employed, as done in Germany in 2002. The use of difference-in-difference estimators will provide quantitative estimates of the effects of this legislation change on a researcher's quantity and quality of publications and patents. In a further analysis the impact on researcher's incentives to found spin-offs will be addressed along with spin-off performance.

\section{Markets for Technology}

In recent years, firms have increasingly contributed to and been confronted with a patent landscape characterised by numerous but marginal inventions, overlapping claims and patent fences. As a result, firms risk their patent applications to be pre-empted or to be infringed upon by rivals. While both aspects constitute major challenges for the appropriation of returns to inventive activity, extant literature suggests that participation in the market for technology might actually resolve or at least alleviate these problems. Christophe Grimpe (Copenhagen Business School) and Katrin Hussinger ${ }^{60}$ investigate these issues empirically. Using a sample of more than 1,100 German manufacturing firms, they show that firms engage in in-licensing as a reaction to pre-empted patents and in cross-licensing if their protected IP was infringed upon. However, these effects vary depending on the fragmentation of technology fields and whether the firm operates in a discrete or complex product industry.

\footnotetext{
54 Zanaj S, Gabszewicz J, Laussel D \& van Ypersele T (2013). Market Games in Successive Oligopolies. Journal of Public Economic Theory, 15(3), 397-410.

${ }^{55}$ Gabszewicz J and Zanaj S (2013). (Un)stable vertical collusive agreements. CREA Discussion Paper 2013-12 (forthcoming in Canadian Journal of Economics).

${ }^{56}$ Université libre de Bruxelles.

${ }^{57}$ Picard PM \& van Pottelsberghe de la Potterie B (2013). Patent Office Governance and Patent Examination Quality. Journal of Public Economics, 104(C), 14-25.

${ }^{58}$ Grimpe C \& Hussinger K (2013). Resource Complementarity and Value Capture in Firm Acquisitions: The Role of Intellectual Property Rights, Strategic Management Journal, doi: 10.1002/smj.2181. ${ }^{59}$ Czarnitzki D and Hussinger K (2013). Patent Rights and Researcher Incentives for Knowledge Production, Disclosure and Commercialisation: Evidence from a Natural Experiment in Germany, Memo. ${ }^{60}$ Grimpe C \& Hussinger K (2013). Pre-empted Patents, Infringed Patents, and Firms' Participation in Markets for Technology. Research policy, doi: 10.1016/j.respol.2013.12.001 (forthcoming 43(3), April 2014)
} 


\section{On the Costs of Knowledge Privatisation}

Patent systems are supposed to spur incentives to innovate by (i) granting inventors temporary monopoly rights that allow them to recoup their research and development (R\&D) investment and (ii) facilitating follow-up inventions by making information about technical inventions available to the public. In other words, patents make technical information available to society at the cost of "privatisation" of this knowledge. Knowledge freely available to the public, as for instance through scientific publications, has been shown to be essential for corporate innovation and productivity growth. The privatisation of knowledge can, hence, hamper innovation and technological progress.

A project led by Katrin Hussinger makes use of a natural experiment to investigate the effects of knowledge privatisation. It is in general hard to examine the effects of patent systems because virtually all industrialised economies have patent systems in place so that a counterfactual situation, i.e. what an economy would look like without patents, is missing as a required benchmark for policy evaluation. This project will make use of the introduction of software patents in the US in the mid-1990s as an event that allows identifying effects of the establishment of patent rights.

This project will, first, investigate the extent to which the introduction of software patents led to a privatisation of knowledge. In other words, the switch from publications in academic journals and proceedings to patents by individual software engineers will be scrutinised. In the next steps, implications of knowledge privatisation for corporate productivity and industry concentration of R\&D will be investigated. Since the introduction of US software patents coincided with the internet revolution control samples from Europe will be used. Europe did not experience an introduction of software patents in the 1990s so that the comparison allows to separate patent regulation induced effects from macroeconomic shocks.

\section{Corporate Venturing}

Industry incumbents are often found to lack the ability to develop drastic innovations internally due to their reliance on existing technologies, established value networks and distinct but rigid routines. In the past decades, incumbent firms started to make intensive use of corporate venturing in order to improve their innovativeness. Corporate venturing can be defined as the creation and development of autonomous units within an organisational context that aim at creating new and radical innovations. A second form of corporate venturing constitutes minority equity investments in external start-up companies. A project led by Katrin Hussinger in partnership with KU Leuven aims at providing large-scale evidence on several aspects of corporate venturing. The findings should help provide managerial advice on how to successfully conduct corporate venturing. The project benefits from the funding support of the Flemish Science Foundation.

\section{Post-merger Integration of Innovative Assets and Innovation Outcome}

The access to technological assets and know-how is an important objective for mergers and acquisitions (M\&As). The combination of firms' knowledge bases can strengthen their technology portfolio and provide opportunities for restructuring their innovation activities. This suggests that M\&As between innovative firms enhance their innovation capabilities providing them with a competitive advantage over market rivals. Prior empirical evidence, however, shows a high variation in post-merger innovation performance. A key challenge for scholars in the field of management science is a better understanding of how technological synergies can be "unlocked" after an M\&A.

This project by Katrin Hussinger contributes to the literature on post-merger innovation by analysing post-merger integration strategies and their impact on innovation. This project is the first to go beyond case study evidence and to provide such an analysis on a large scale. A method for making different post-merger integration strategies for innovative assets visible on a large scale will be proposed. The method focuses on changes of the inventive labour force composition before and after the M\&A. Based on different inventor employment patterns, different integration strategies will be identified.

Implications for innovation outcome and quality will be analysed within the framework of patent production functions. The timing of post-merger success of specific strategies (e.g. more versus less restructuring) will receive special attention. Furthermore, individual inventor profiles, their successful combination and implications for innovation outcome will be studied. The empirical analysis will make use of advanced econometric techniques, including panel count data models and quasi-experimental methods.

The results of the project will improve our understanding of post-merger innovation performance and inform managers about promising post-merger integration strategies. Recommendations for integration strategies under specific economic and strategic conditions will be made.

\section{(iii) Innovation and Management Practices}

Innovation and technological change are the drivers of growth in modern, knowledge-based economies. Successful innovation requires that firms master a fast-growing and diversified set of competences, skills and knowledge. Management practices within the firm as well as strategic alliances and inter-organisational networks play a crucial role in the successful implementation of innovations. 


\section{The Dynamics of Inter-organisational Networks}

Firms are increasingly forming collaborative agreements with other (possibly competing) organisations to reach beyond their boundaries and access the complementary resources they do not have in-house. Nicolas Jonard with Joel Baum (Rotman School of Management) and Robin Cowan (University of Maastricht and Strasbourg $)^{61}$, looks at how patterns of inter-firm connections create network-based advantages for well-positioned firms, asking about the value of open versus closed network positions. A quantitative evaluation of the performance of a network strategy turns out to be quite tricky because network positions can influence both the mean and variance of firm performance. A simulation study, designed to examine network performance effects in both pooled cross-section and within-firm over time across a wide range of conditions, counsels caution in drawing implications for network strategies. These findings have implications for research on network effects, and more broadly for drawing strategic inferences from studies of firm performance in pooled cross-section.

Nicolas Jonard and Tristan Boyer (IPAG Business School, Paris) ${ }^{62}$ examine the conditions needed to ensure the efficient diffusion of cooperation in an infinite population of networked individuals via imitative learning. The more the agents interact among themselves rather than with players, who are closer to or further away from the initial seed group, the easier it is for efficient contagion to take place. They also find that networks organised as dense clusters sparsely connected to one another tend to resist efficient contagion. The likelihood of efficient contagion in a network increases when information neighbourhoods extend beyond interaction neighbourhoods.

Another research theme in the area of networks and innovation is the properties of the innovation process in terms of complementarity and similarity of the partners' knowledge endowments. This research is developed with Robin Cowan (University of Maastricht) and Melissa Schilling (Stern School of Business).

\section{The Psychology of Organisational Behaviour and Networks}

Organisational networks are interpersonal networks. The energy and commitment of members of the organisation both affect and are affected by problem-solving and more generally organisational performance. To model and analyse this coevolution, and eventually to improve our understanding of the emergence, functioning and consequences of organisational networks, economic and psychological theories and methods must be reconciled. This theme considers the mediating role of stress in multiplex networks, analysing how the organisational and social networks interact to affect organisational members' performance, and the ambiguous effect of this interaction at the level of the whole organisation endowments. This research project is led by Nicolas Jonard in collaboration with Robin Cowan (University of Maastricht) and Rifka Weehuizen (European Science Foundation).

\section{Innovation Practices of Newly Emerging or Established Firms}

An ongoing project conducted by Denise E Fletcher in collaboration with John Bessant (Exeter University and guest professor at the UL), Fredrik Hacklin (ETH, Zurich) and Marc Hallin (ECARES ${ }^{63}$, Solvay Brussels School of Economics and Management), is concerned with understanding and theorising the innovation practices enacted by both small entrepreneurial firms and established organisations in growing or maturing markets.

\section{(iv) Strategic Allocation of Resources}

\section{Returns to Acquisitions in the US Software Industry}

On the basis of a sample of 5,079 acquisitions by US software industry companies during 1988-2008, Matthias Brauer ${ }^{64}$ with Tomi Laamanen (University of St. Gallen) and Olli Junna (UPM-Kymmene Corporation, Helsinki) find that acquisitions of divested assets outperform acquisitions of privately held firms, which in turn outperform acquisitions of publicly held firms. While the higher returns for acquisitions of divested assets relative to stand-alone acquisition targets can be explained by market efficiency arguments, seller distress and improved asset fit further enhance the positive returns of acquirers of divested assets consistent with the relative bargaining power explanation. It is also found that the effects of these buyer bargaining advantages are mutually strengthening and that they also hold for longer-term acquirer performance.

\section{Strategic Divergence: Evidence from Europe}

Coordinating consistent strategy implementation has been identified a key challenge for multinational corporations. Matthias Brauer and Marc Heitmann (University of Hamburg) ${ }^{65}$ use a large-scale data base to empirically investigate the antecedents and temporal dynamics of strategic divergence. Strategic divergence is the deviation of a firm's resource allocation decisions with its articulated concept of corporate strategy. Decision type, operational and divisional manager involvement in decision making and structural context changes exert a significant influence on strategic divergence. Importantly, results further suggest that firms' levels of strategic divergence tend to increase over time and that the antecedents of strategic divergence have a differential impact as time passes.

\footnotetext{
${ }^{61}$ Baum J, Cowan R \& Jonard N (2013). Does evidence of network effects on firm performance in pooled cross-section support prescriptions for network strategy? Strategic Management Journal, doi: 10.1002/smj.2133 (forthcoming 35: 652-667, May 2014).

${ }^{62}$ Boyer T \& Jonard N (2010). Imitation and Efficient Contagion. CREA Discussion Papers 2010-03 (forthcoming in Journal of Economic Behavior \& Organization, doi: 10.1016/j.jebo. 2014.01.009, 100: 20-32, April 2014).

${ }^{63}$ European Centre for Advanced Research in Economics and Statistics.

${ }^{64}$ Laamanen T, Brauer M and Junna 0 (2013). Performance of Acquirers of Divested Assets: Evidence from the US Software Industry. Strategic Management Journal doi: 10.1002/smj.2120 (forthcoming) ${ }^{65}$ Brauer M \& Heitmann M (2013). Determinants, Antecedents and Temporal Dynamics of Strategic Divergence: Evidence from Europe. Journal of World Business, 48(1), 110-121.
} 


\section{The Performance of Mutual Funds}

A project led by Virginie Terraza ${ }^{66}$ in collaboration with the University of Lorraine, the University of Montpellier I and the University of Paris-Dauphine studies the performance of mutual funds distinguished by their domicile. It uses a structural analysis to construct fund synthetic indexes that capture the time structure of the mutual fund performance. The project addresses the challenges associated with replicating traditional financial indices. It benefits from the funding support of the Lorraine region.

\section{Corporate Governance and Entrepreneurship}

Innovation and growth are associated to successful entrepreneurship and corporate governance. This research area is devoted to the conditions and contexts under which new businesses can be successfully started and grown. Aspects of corporate governance such as risk management, auditing and financial accounting are also crucial factors for the development of entities. The role of asymmetric information and incentive mechanisms underlies these questions. It is a domain where interactions between economics and management can be usefully exploited.

The faculty members involved in these research activities are Denise E Fletcher, Katrin Hussinger, Anke Muessig and Nicolas Jonard.

\section{(i) Corporate Governance}

Corporate Governance is the system by which companies are directed and controlled. The focus in this research domain lies currently on the role of a company's board as well as on accounting and audit issues. The role of asymmetric information (management versus stakeholders) and incentive mechanisms underlies the research questions in the accounting and audit research axis.

\section{Corporate Governance and the Structure of Boards}

Corporate boards are characterised by large extents of director commonality. The phenomenon is manifest across all countries and industries, implying the existing of indirect routes by which knowledge and decisions generated at one board can become inputs for other boards. Empirical research has emphasised how such interlocks matter in changes in corporate structure, acquisition strategies, anti-takeover tactics, the determination of compensation levels and many more corporate governance variables. Using data collected while the project was funded by FNR under its CORE initiative, this theme examines the properties of board membership networks in a very large cross-section of countries, testing the plausibility of the small-world hypothesis and seeking to formulate social processes of board affiliation. The project is led by Nicolas Jonard, with Malika Hamadi, Andreas Heinen (University of Cergy, France) and Alfonso Valdesogo (University Carlos III of Madrid).

\section{Risk Reporting and Accounting Conservatism}

This research project deals with firms' risk reporting behaviours in management commentaries and its accounting conservatism in selected EU member states. The project is led by Anke Muessig. It is a joint research project with Kerstin Lopatta and Carl von Ossietzky from the University of Oldenburg.

\section{Oversight Systems over Auditors}

A project led by Anke Muessig and funded by the UL examines how one can assure high-quality statutory auditing of financial statements. The background is the spectacular balance sheet manipulations and corporate failures of the recent financial and economic crisis. One course of action is to revise existing legal regulations and auditing standards and establish new ones to improve auditing quality. Another is to implement and improve oversight systems over statutory auditors to ensure that audits are conducted in accordance with professional, regulatory, and legal requirements. This approach is considered a key mechanism and a major step towards ensuring reasonable audit quality. Oversight systems enhance the credibility of published financial information and protect shareholders, investors, creditors, and other interested parties. Do the economic crisis and past balance sheet manipulations mean that both auditors and oversight systems have failed? Are they effective, profession-independent, and trustworthy? This ongoing research project will assess current developments in establishing profession-independent auditor oversight systems.

\section{(ii) Entrepreneurship}

A high proportion of entrepreneurial endeavours begin in relationships within a previous firm or within households. Several research projects are devoted to a better understanding of the factors that contribute to the launching, organisation and success of entrepreneurial activities.

${ }^{66}$ Terraza V \& Razafitombo H (Eds.) (2013). Understanding Investment Funds- Insights from Performance and Risk Analysis. London, England,Palgrave. 
Is Success Hereditary?

A common phenomenon in entrepreneurship is that employees turn away from employment to found their own businesses. Prior literature discusses the former employers' characteristics that influence the creation of entrepreneurial ventures. An investigation of whether these characteristics also affect the success of the spawned ventures is missing so far. Katrin Hussinger ${ }^{67}$, with Johannes Dick, Boris Blumberg and John Hagedoorn from the University of Maastricht, uses linked employee-employer data for the Netherlands over the period 1999-2004 to investigate which factors are crucial for success. They show that entrepreneurial ventures spawned by well performing firms are financially more successful than ventures stemming from poorly performing firms. This suggests that spawned entrepreneurs are able to exploit valuable knowledge from their previous employers which impacts their ventures' performance positively.

\section{Understanding Entrepreneurial Work}

An interdisciplinary research programme led by Denise E Fletcher centres on developing sociological understandings of entrepreneurial forms of work. The premise is that a high proportion of entrepreneurial endeavours begin in relationships within households, families or couples. Combining theories from management and sociology, Denise E Fletcher and associated researchers examine how emotions, boundaries, roles and resources are negotiated within entrepreneurial work. From a practitioner or policy perspective, this research stresses how the fundamental institutions of family and work interrelate at an 'everyday' level to produce a complex range of business forms that contribute to local economic development.

In collaboration with Paul Selden, Denise E Fletcher examines the theoretical basis of entrepreneurial opportunity formation. She also founded a consortium between STATEC and the Public Research Centre Henri Tudor to enter the Global Entrepreneurship Monitor (GEM) project for Luxembourg. GEM is the largest ongoing study of entrepreneurial dynamics in the world. It explores the role of entrepreneurship in national economic growth, unveiling detailed national features and characteristics associated with entrepreneurial activity. Funded by the Luxembourg Chamber of Commerce, this project provides an analysis of a survey of 2000 Luxembourgish adult residents to assess their entrepreneurial intentions.

\section{E. Empirical Methods}

This research area is devoted to the study of empirical techniques relevant for understanding and evaluating economic models using cross-sectional and panel data. These empirical techniques are used in many of the previously listed research projects. Our research effort also focuses on contributing towards the advancement of econometric methodology. In particular, we are interested in the development and use of new statistical methods and tools to estimate and test micro-econometric models without making unnecessary parametric or exogeneity assumptions.

Gautam Tripathi is involved in several projects. With Thomas Severini (Northwestern University) ${ }^{68}$, he evaluates estimators by comparing their asymptotic variances and discusses the role of the efficiency bound. With Tao Chen (University of Waterloo) ${ }^{69}$, he tests the assumption of conditional symmetry used to estimate regression models with endogenous regressors without making distributional assumptions. More recently, Chen and Tripathi ${ }^{70}$ propose a test for the conditional symmetry assumption maintained in the symmetrically trimmed least-squares approach which is widely used to identify and estimate censored or truncated regression models. Ongoing research projects include "Nonparametric estimation of returns to scale" (with Thomas Severini), "Integrated likelihood based inference for nonlinear panel data models with unobserved effects" (with Martin Schumann (PhD) and Thomas Severini), and "Estimating censored regression models with endogenous regressors under conditional symmetry" (with Tao Chen).
${ }^{67}$ Dick J, Hussinger K, Blumberg B \& Hagedoorn J (2013). Is Success Hereditary? Evidence on the Performance of Spawned Ventures. Small Business Economics, 40 (4), 911-931. ${ }^{68}$ Severini T \& Tripathi G (2013). Semiparametric Efficiency Bounds for Microeconometric Models: A Survey. Foundations \& Trends in Econometrics, 6, 163-397.

${ }^{69}$ Chen T \& Tripathi G (2013). Testing Conditional Symmetry Without Smoothing. Journal of Nonparametric Statistics, 25, 273-313.

${ }^{70}$ Chen T \& Tripathi G (2014), A Simple Consistent Test of Conditional Symmetry in Symmetrically Trimmed Tobit Models. CREA Discussion Paper 2014-04. 


\section{Funded Projects}

\begin{abstract}
Some research programmes conducted at CREA benefit from extra funding resources allocated on a competitive basis. The main sources are currently the Luxembourg National Research Fund (FNR), the University of Luxembourg's research fund (PUL), the European COST programme, and some others. These extra resources are most important as they help develop international collaborations, attract promising Post-doc researchers and finance $\mathrm{PhD}$ students. In 2013, 10 running projects were benefiting from extra financial support. These projects are briefly described below.
\end{abstract}

\section{Project Title:}

\section{International Migration Policy and Law Analysis Database (IMPALA)}

Area: Regional Development and Globalisation

Funding: CORE-FNR

(Fond National de la Recherche, Luxembourg)

Period covered: 01/09/2012 to 31/08/2015

Supervisor: Michel Beine

Collaborators: Diana A Bratean and Bénédicte Souy (Scientific Collaborators)

Partners: University of Harvard, University of Amsterdam, University of Sydney and the London School of Economics.

Summary: Governments adopt a variety of approaches to regulate immigration, and make adjustments to these policies frequently. But currently there exist no comprehensive, cross-nationally comparable data on immigration laws and policies and how they have changed over time. This is a major problem for ongoing research on the determinants and impacts of immigration policies. The project is aimed at addressing this problem by compiling and analysing comparable data on immigration laws and policies in 26 major recipient countries from 1960 until the present, with annual updates to follow.

\section{Project Title:}

\section{Endogenous Occupational Choice and Migration}

Area: Regional Development and Globalisation

Funding: PUL-University of Luxembourg

Period covered: 01/01/2013-31/12/2014
Supervisor: Patrice Pieretti and Benteng Zou

Collaborators: Yutao Han (PhD)

Partners: Luca Marchiori (BCL), Herbert Dawid (IMW, Bielefeld University), I-ling Shen (Milken Institute, USA), Carmen Camacho (CNRS, Paris 1), Jean-François Maystadt (IFPRI ${ }^{71}$, Washington DC), Tianglong Wang (China Center of International Economic Exchange, Beijing), Frédéric Docquier (IRES, Université catholique de Louvain)

Summary: This project focuses on the impact of immigration on educational choices and on the skill distribution of natives. Although immigration flows may lead to lower wages for a particular skill group, the induced changes in the skill distribution may produce overall beneficial results. We investigate this issue within a general equilibrium occupational choice model with three sectors: low-skill, high-skill and a public sector. Differences in learning abilities and in local skills (e.g. language and citizenship) are taken into account. The second objective of this project is to re-examine the implications of immigration for the financing of the welfare state, in particular pension systems. To this end, we use an overlapping generations model with endogenous fertility. The model will next be expanded to also include endogenous migration decisions.

\section{Project Title:}

\section{Tax Havens and Evasion}

Area: Regional Development and Globalisation

Funding: PUL-University of Luxembourg

Period covered: 01/01/2013-31/12/2015

Supervisor: Skerdilajda Zanaj

Collaborators: Patrice Pieretti, Pierre M Picard, Jacques Thisse (CORE, Université catholique de Louvain, Visiting Professor)

Partners: Simone Moriconi (Università Cattolica del Sacro Cuore, Milano), Jean Gabszewicz (CORE, Université catholique de Louvain)

Summary: This project has two interdependent themes. First, we ask how international banking competition is affected by tax evasion. Most of the existing literature emphasises the negative role of tax havens on the level of public goods provided at the global level and on the role of such centres on illegal activities such as money laundering. In this project, we aim at identifying a new channel through which tax evasion performed in offshore centres can affect the overall welfare of investors: attracting evader distorts competition among banks and lowers interest rates supplied to honest investors. Secondly, we aim at identifying the optimal strategies that

${ }^{71}$ International Food Policy Research Institute, Washington, USA. 
international banking centres should follow to face the international pressure. To do so it is necessary to clarify the difference among the existing tax havens in the global financial markets.

\section{Project Title:}

\section{Economic Geography and Quality Heterogeneity}

Area: Regional Development and Globalisation

Funding: PUL-University of Luxembourg

Period covered: 01/09/2011-31/08/2014

Supervisor: Pierre M Picard

Collaborators: Ha Man N'Guyen (Post-doc: 01/10/201130/09/2013), Masashige Hamano (Post-doc: 01/09/2011$31 / 03 / 2013)$

Partners: Rabba Amir (University of Arizona), Simone Moriconi (Università Cattolica del Sacro Cuore, Milano)

Summary: In this project we aim to build and discuss the impact of product quality in economic geography models where consumers consume manufacturing products with different qualities and characteristics. We focus on models where capital and entrepreneurs are free to move across borders. We aim to check the claims that firms selling the higher quality goods select the region hosting the largest number of consumers and that larger regions get better access to the higher quality products. We also ask the question of how firms' spatial distribution depends on the varieties and their qualities, and whether the introduction of quality heterogeneity smoothens the agglomeration patterns predicted by the economic geography framework. Finally, we will attempt to understand how firms can indirectly shape the economic geography by improving the quality and characteristics of their products and how the multinational production structure of firms can affect the quality of produced and traded goods.

\section{Project Title:}

The EU in the New Complex Geography of Economic Systems: Models, Tools and Policy Evaluation

Area: Regional Development and Globalisation

Funding: European Cooperation in Science and Technology (COST)

Period covered: 01/01/2012 to 30/11/2015

Supervisor: Benteng Zou

Partners: Chair of project is with Pasquale Commendatore (Univer- sità di Napoli 'Federico II') and Ingrid Kubin (WU Vienna University of Economics and Business), network of 80 members

Summary: Spatial inequalities are evolving through time following complex patterns determined by economic, geographical, institutional and social factors. The New Economic Geography approach describes economic systems as very simplified spatial structures. The action aims at developing a more sophisticated modelling of the EU visualised as an evolving trade network with a specific topology determined by the number and strength of national, regional and local links. The expected results will provide a basis for an improved evaluation of such policies, in particular for the European Cohesion Policy, considering their impact on the welfare level of EU citizens and its geographical distribution. To achieve this objective this action will enhance interdisciplinary networking combining recent approaches in economics with the most advanced mathematical and computational methods for analysing complex and non-linear systems.

\section{Project Title:}

\section{The Economics of Carbon Capture and Storage}

Area: Macroeconomics and Growth

Funding: PUL-University of Luxembourg

Period covered: 1/01/2011-28/02/2014

\section{Supervisor: Benteng Zou and Luisito Bertinelli}

Collaborators: Antonia Margherita and Déborah Schwarz (Scientific Collaborators)

Partners: Ingmar Schumacher (IPAG Business School, Paris), Eric Strobl (Ecole Polytechnique, Paris), Carmen Camacho (CNRS, Paris 1)

Summary: Adopting clean technologies is a long term process which requires structural changes in the production and consumption habits. In the present project, we intend to focus more on short term issues related to pollution reduction and analyse pollution abatement in a dynamic model. Furthermore, trans-boundary pollution will be considered and modelled as a common state variable. As we are interested in analysing the short run, pollution reduction will be tackled via abatement rather than the adoption of cleaner technologies. This is consistent with short term horizon issues of pollution reduction, as compared to long term reduction, which might be based on increased efficiency of technologies. 


\section{Project Title:}

\section{Wage Dynamics and Automatic Indexation}

Area: Macroeconomics and Growth

Funding: Observatoire de la Formation des Prix

Period covered: 01/02/2013-01/03/2014

Supervisor: Arnaud Bourgain and Henri Sneessens

Collaborators: Déborah Schwarz (Scientific Collaborator)

Partners: Fatemeh Shadman (IRES, Université catholique de Louvain)

Summary: The objective is to examine whether wage dynamics are different in countries with or without automatic wage indexation clauses. More specifically, we want to check whether there are significant differences in (i) the long run indexation coefficient; (ii) the long run effect of unemployment on real wages; and (iii) the short run wage dynamics. To this end, we use annual data on four countries (Belgium, Luxembourg, France, Germany) over the period 1970-2012 and estimate an VAR-ECM model.

\section{Project Title:}

Patent Rights and Researcher Incentives for Knowledge Production, Disclosure and Commercialisation: Evidence from a Natural Experiment in Germany

Area: Strategic Interactions and Organisations

Funding: SEEK ${ }^{72}$ Programme at ZEW ${ }^{73}$, Mannheim

Period covered: 01/04/2013-30/09/2014

Supervisor: Katrin Hussinger

Partners: Dirk Czarnitzki (KU Leuven), Andrew A Toole (Economic Research Service, US Dept. of Agriculture, Washington), Paula Schliessler (ZEW, Mannheim)

Summary: This project will use a natural experiment to identify the causal effects of transferring patent rights to the university on the incentives for academic researchers to produce and publicly disseminate new knowledge, and on the profile of academic founders who pursue commercialisation through university spin-off companies. Our natural experiment exploits the institutional structure of the public research system in Germany. In 2002, the German government changed the employment law so that university researchers no longer held the patent rights to their inventions. In Germany's other public research organisations (PRO), academic researchers never had this "professor's privilege." This allows us to exploit PRO researchers as a control group not affected by the ownership change. Using difference-in-difference estimators the outcomes to be studied are a researcher's quantity and quality of publications and patents. In a further analysis the impact on researcher's incentives to found spinoffs will be addressed along with spin-off performance.

\section{Project Title:}

\section{Corporate Venturing and Innovation: Knowledge Creation and Spill-over Effects}

Area: Strategic Interactions and Organisations

Funding: Flemish Science Foundation

Period covered: 01/01/2013-31/12/2016

Supervisor: Katrin Hussinger

Partners: Dirk Czarnitzki (KU Leuven)

Summary: Innovation is considered as one of the most important drivers for the competitiveness and profitability of incumbent firms. Nevertheless, industry incumbents are often found to lack the ability to develop drastic innovations internally due to their reliance on existing technologies, established value networks and distinct, but rigid routines. In the past decades, incumbent firms started to make intensive use of corporate venturing in order to improve their innovativeness. The academic literature on the topic of corporate venturing is, despite its growing importance, still in its infancy. This project aims at providing evidence on the effectiveness of firms' corporate venturing strategies. It will contribute to the academic literature by offering large-scale evidence on several aspects of corporate venturing and it will provide managerial advice on how to successfully conduct corporate venturing.

\section{Project Title:}

Oversight Systems for Auditors From Path Dependence to Institutional Evolution?

Area: Corporate Governance and Entrepreneurship

Funding: PUL-University of Luxembourg

Period covered: 01/09/2012-31/08/2015

Supervisor: Anke Muessig

\footnotetext{
${ }^{2}$ Strengthening Efficiency and Competitiveness in the European Knowledge Economies (SEEK) in Centre for European Economic Research (ZEW)

${ }^{73}$ Centre for European Economic Research, Manheim, Germany.
} 
Collaborators: Lukas Loehlein (PhD)

Summary: How can high-quality statutory auditing of financial statements be assured? In only a few of the recent major corporate failures have audit reports provided clues that major asset write-downs would be necessary. One course of action is to revise existing legal regulations and auditing standards and establish new ones to improve auditing quality. Another is to implement and improve oversight systems over statutory auditors to ensure that audits are conducted in accordance with professional, regulatory, and legal requirements.

This research project will assess current developments in establishing profession-independent auditor oversight systems. The overall aim is to explore the origins of and reasons for the diversity of current, profession-near oversight systems, despite the fact that all countries encounter similar pressure to establish public (i.e. profession-independent) oversight systems. Finally, an evaluation will be made of the characteristics of an oversight system that would best meet the public's expectations and enhance confidence in the capital markets. 


\section{PhD Training}

Providing advanced education in Economics and in Management is part of CREA's mission. A Doctoral School in Economics and Finance was launched in 2011, at the same time as a Research Master track was established within the Master in Economics and Finance programme. Similar training programmes should be developed in the field of Management with the financial support of the Luxembourg Chamber of Commerce.

The number of PhD students has increased steadily, in line with the number of CREA faculty members. The first PhD degree was awarded in 2010, two were awarded in 2013 and at least three should be awarded in 2014. Fifteen PhD students are currently enrolled in a doctoral programme in Economics or Management.

\section{The Doctoral School in Economics and Finance (DSEF)}

The Doctoral School in Economics and Finance (DSEF) is a joint venture between CREA and the LSF - Luxembourg School of Finance, launched in October 2011. The DSEF aims at providing doctoral candidates a research environment meeting the standards of the best European universities. The programme is designed to give to all students a solid background in both economics and/ or finance. Towards this aim, the DSEF internally offers a series of doctoral courses in specialised topics in advanced macro-economics, micro-economics, finance and mathematics. It regularly invites internationally re-known researchers to teach research-frontier topics in finance and economics (Prof Yves Zenou, University of Stockholm; Prof Oded Galor, Brown University; Prof David Martimort, Paris School of Economics; Prof Andrea Attar, Toulouse School of Economics etc.). The DSEF promotes students' participation to summer and winter courses. It also supports a Doctoral Student Society. Finally, the DSEF has cooperation agreements in doctoral education (PhD training and supervision) with two important research institutions in Economics in Luxembourg, the CEPS/INSTEAD and STATEC.

\section{Completed PhD Dissertations in Economics and Management since 2010}

Robert Vermeulen - Essays in International Finance, 2010 (Supervisor: Michel Beine)

Maurizio Cortesi - The Dynamics of Trust in Social Networks, 2012 (Supervisor: Nicolas Jonard)

Ridwan Rusli - Governance and Contracts in Developing Country Natural Resource and Energy Sectors, 2013 (Supervisor: Pierre M Picard)
Wessel Vermeulen - Essays on Dutch Disease Economies, 2013 (Supervisor: Michel Beine)

\section{Ongoing PhD Projects in Economics and Management}

Jean-Nicolas Reyt - Mobile Work, Psychological Distance and Innovation Behaviour (expected February 2014)(Supervisor: Nicolas Jonard)

Yutao Han - Dynamic Tax and Institutional Competition (expected May 2014) (Supervisor: Patrice Pieretti)

Erica Perego - The Role of Rare Disasters in a DSGE framework (expected October 2014) (Supervisor: Henri Sneessens)

Amer Tabakovic - Essays on Economic Growth Theory (Supervisor: Andreas Irmen)

Christian Pietsch - The Information Content of Financial Disclosure: Market Behaviour and Cognitive Information Processing of Corporate News (Supervisor: Anke Muessig)

Xi Wan - Airport Externalities: Congestion and Noise Disturbance (FNR-AFR scholarship) (Supervisor: Pierre M Picard)

Claire-Oceane Chevallier - Financial Frictions and Macroeconomic Fluctuations (FNR-AFR scholarship) (Supervisor: Henri Sneessens)

Lukas Loehlein - Audit Oversight Regimes (PUL scholarship) (Supervisor: Anke Muessig)

Sarah El Joueidi - Of Competition and Innovation, Twists and Turns in the Financial Sector (Supervisor: Pierre M Picard)

Dimitrios Mavridis - Essays on Dynamic Economics : Dynamic Games, Bayesian Learning, and Fiscal Policy (Supervisor: Christos Koulovatianos)

Martin Schumann - Three Essays in Econometrics (Supervisor: Gautam Tripathi)

Marco Delogu - Essays in International Migration (Supervisor: Michel Beine)

Giuseppe Pulina - Bank Secrecy, Tax Treaties and Institutional Competition (Supervisor: Patrice Pieretti)

Anne Tryba - Entrepreneurial Teams (FNR-AFR scholarship) (Supervisors: Denise E Fletcher and Katrin Hussinger)

Rocky Adiguna - Organisational Culture and Family Business (Supervisor: Denise E Fletcher)

Thorsten Doherr - Search Algorithms in Economic Research (Supervisor: Katrin Hussinger)

34 | CREA - RESEARCH REPORT 2013 


\section{6}

\section{Post-Doctoral}

\section{Projects}

Post-doctoral projects are a most effective way to help junior researchers to develop their own research projects, as well as promote cross-institutional fertilisation. CREA currently hosts 4 post-doctoral researchers. These positions are funded by the University of Luxembourg or by the FNR - the Luxembourg National Research Fund.

\section{Completed}

Elisabeta Lodigiani (2008-2010).

International Economics, Developments Economics, Migration (Project leader: Michel Beine)

Luca Marchiori (2009-2011)

Economics of Human Capital Migration, International Migration (Project leader: Benteng Zou)

Quentin David (2009-2013).

Urban Economics, Economics of Education

(Project leader: Pierre M Picard)

Masashige Hamano (2011-2013).

Economic Geography and Product Quality (PUL scholarship)

(Project leader: Pierre M Picard)

Laura Rovegno (2013).

International Trade, Trade Policy, Industrial Organisation,

Microeconometrics

(Project leaders: Patrice Pieretti, Skerdilajda Zanaj)

\section{Ongoing}

Ha Man N'Guyen (2011-2014).

Economic Geography and Product Quality (PUL scholarship) (Project leader: Pierre M Picard)

Anastasia Litina (2012-)

Comparative Development, Economic Growth, Aging

(Project leader: Andreas Irmen)

Jean-François Carpantier (2012- )

Economic Analysis of Commodities and Natural Resources (Project leader: Michel Beine)

Alessandro Tampieri (2013- )

Vertical Differentiation, Trade and Geography

(Project leader: Pierre M Picard) 


\section{Events}

\section{and Exchanges}

Conferences and seminars are a most effective way to promote exchanges across institutions and disseminate research results. We list in this section all the events organised at CREA, as well as all research presentations made by CREA members in international conferences, workshops or seminars in 2013.

\section{A. Conferences Organised at the University of Luxembourg}

CREA's 20th Anniversary Conference, 14 January 2014

To celebrate its 20th anniversary, CREA organised a special conference on 14 January 2014. Philippe Aghion, Robert C Waggoner Professor of Economics, University of Harvard (USA) gave a lecture on Growth and The Smart State: Implications for Growth Policy in Europe.

Other events will be organised during the year 2014 to celebrate this anniversary, both in the field of Economics and of Management.

\section{The CREA Conference Talks on Economics}

The CREA Conference Talks on Economics are yearly conferences dedicated to a wide audience.

- 1st CREA Conference Talks on Economics, 1 April 2011 Basic Income and Income Redistribution

Guest Speakers: Tony Atkinson, Fellow of Nuffield College, Oxford and Centennial Professor at the LSE; Philippe Van Parijs, Professor at the Université Catholique de Louvain ; Tito Boeri, Professor of Economics at Bocconi University and Scientific Director of the Fondazione Rodolfo Debenedetti.

Round Table: Serge Allegrezza, Director of STATEC ; Frédéric Berger, CEPS/INSTEAD ; Muriel Bouchet, Banque Centrale du Luxembourg ; Robert Kieffer, Président de la Caisse Nationale d'Assurance ; Jürgen Stoldt, Director of Forum.

- 2d CREA Conference Talks on Economics, 22 May 2012 Unified Growth Theory and ComparativeEconomic Development

Guest Speaker: Oded Galor, Herbert H Goldberger Professor of Economics, Brown University.
- 3d CREA Conference Talks on Economics, 22 November 2013 Monetary Policy and Global Capital Markets

Guest Speaker: Paul De Grauwe, John Paulson Chair in European Political Economy, The London School of Economics.

- 4th CREA Conference Talks on Economics, 28 May 2014 Tax Competition and Public Policy

Guest Speakers: Robin Boadway, Emeritus Professor of Economics, Queen's University, Kingston Ontario (Canada); Raouf Boucekkine, Professor and Research Director, AMSE-Aix-Marseille School of Economics (France); Kai Konrad, Professor and Director of the Department of Public Economics, Max Planck Institute, Munich (Germany); Alexander Rust, ATOZ Chair for European and International Taxation, Law Department, University of Luxembourg; Myrna Wooders, Professor of Economics, Vanderbilt University (USA).

\section{B. The CREA Lunch Seminars in Economics and Management}

The CREA Lunch Seminar in Economics and Management welcomes, every two weeks, a guest speaker from a foreign research centre. The seminars cover a wide range of topics and are meant to foster cross-institutional exchanges. It benefits from the financial support of the FNR. Nineteen seminars were organised in 2013.

16-Jan-13 - Claude d'Aspremont, Université catholique de Louvain Hawks and doves in segmented markets: a formal approach to competitive aggressiveness

30-Jan-13 - Emanuele Tarantino, University of Bologna Vertical Integration with Complementary Inputs

31-Jan-13 - Robert Breunig, Australian National University Child Care in Australia

27-Feb-13 - Jennifer Pédussel Wu, Berlin School of Economics and Law Immigrant Specificity and the Relationship between Immigration and Trade: Theory and Evidence

6-Mar-13 - Giovanni Peri, University of California Davis STEM Workers, H1B Visas and Productivity in US Cities

13-Mar-13 - Bertrand Koebel, Université de Strasbourg Fixed cost, Variable Cost and the Markup

27-Mar-13 - Benny Geys, BI Norwegian Business School and WZB Berlin

Religious Heterogeneity and Fiscal Policy: Evidence from German Reunification 
13-Feb-13 - Xenia Matschke, Universität Trier US Multinationals and Preferential Market Access

24-Apr-13 - Ingmar Schumacher, IPAG Business School, Paris Environmental Attitude, Belief and Voting Behavior

8-May-13 - Gianmarco Ottaviano, London School of Economics The Buyer Margins of Firms' Exports

15-May-13 - Amit Khandelwal, Columbia Graduate School of Business Prices, Markups and Trade Reform

5-Jun-13 - Alexander Ludwig, University of Cologne Optimal Progressive Taxation and Education Subsidies in a Model of Endogenous Human

19-Jun-13 - Alain Durré, European Central Bank Cagan, Sims, Leeper, Woodford and Others: Theoretical Digression on the Policy Mix

25-Sep-13 - Raouf Boucekkine, GREQAM, Aix-Marseille Financial Globalization, Growth and Welfare: An AK Theory of International Borrowing without Commitment

9-Oct-1 - Olivier De Lagrandville, Stanford University Why Is Optimal Growth Theory Mute in these Hard Times? Restoring its Rightful Voice

6-Nov-13 - Salvador Ortiguiera, Universidad Carlos III de Madrid How Important is Intra-household Risk Sharing for Savings and Labor Supply

13-Nov-13 - Niels Johannesen,University of Copenhagen Can Taxes Tame the Banks? Evidence from the European Bank Levies

4-Dec-13 - Hendrik Hakenes, University of Bonn On the Existence and Prevention of Speculative Bubbles

18-Dec-13 - Jens Suedekum, Universität Duisburg-Essen The rise of the East and the Far East: German Labor Markets and Trade Integration

\section{The CREA Research Seminars}

The CREA Research Seminar is mainly an internal event. It gives CREA researchers the opportunity to present and discuss their ongoing research work with colleagues. The seminar also remains open to researchers from other institutions. Twelve seminars were organised in 2013.

9-Jan-2013 - Anastasia Litina, CREA, University of Luxembourg Public Versus Private Education: Is There a Role for Institutions

23-Jan-2013 - Philippe Van Kerm, CEPS/INSTEAD

Trends in Individual Income Growth: Measurement Methods and British Evidence

6-Feb-13 - Antonio Cosma, CREA, University of Luxembourg Option Pricing by Recursive Projections

7-Mar-13 - Masashige Hamano, CREA, University of Luxembourg Extensive and Intensive Margins and the Choice of Exchange Rate Regimes

18-Apr-13 - Ha Manh N'Guyen, CREA, University of Luxembourg Product Quality, Competition and Heterogeneous Firms

30-May-13 - Pierre M Picard, CREA, University of Luxembourg Spatial Segregation and Urban Structure

12-Jun-13 - Christos Koulovationos, CREA, University of Luxembourg Confronting the Representative Consumer with Household-size Heterogeneity

13-June-13 - Conchita D'Ambrosio, INSIDE7, University of Luxembourg Poverty and Well-being: Panel Evidence from Germany

19-0ct-13 - Alessandro Tampieri, CREA, University of Luxembourg Students' Social Origins and Targeted Grade Inflation

21-Nov-13 - Katrin Hussinger, CREA, University of Luxembourg Insider Trading on Superior Information: Evidence from a Natural Experiment

28-Nov-13 - Matthias Brauer, CREA, University of Luxembourg Selling What You Love : Divestiture Activity in Family Controlled Firms

05-Dec-13 - Anastasia Litina, CREA, University of Luxembourg Religiosity and Growth Revisited: Estimating a Causal Effect 


\section{Presentations in International Conferences, Workshops, Seminars}

\section{Michel Beine}

- The determinants of International Mobility of Students, Norface-Migration conference "Global Development, new frontiers", University College London, UK , 10-13 April 2013.

- Business Cycles and International Migration among OECD Countries (Bricongne JC, Bourgeon P), at Séminaire "Développement et Mondialisation" Paris School of Economics, Paris, France, 7 November 2013.

- Aggregate Fluctuations on International Migration, 3rd Conference on Immigration in OECD Countries, OECD Paris, France. 12 December 2013.

- Comparing Immigration Policies Across Countries and Over Time: Early estimates from IMPALA, CESifo Economic Studies Conference on Migration, Munich, Germany , 13-14 December 2013.

\section{Luisito Bertinelli}

- Pollution and Child Mortality: the Case of Tropospheric Ozone in Sub-Saharan Africa (Bertinelli L \& Strobl E) at ERMES (University Paris II), Paris, France, 20 June 2013.

- Pollution and Child Mortality: the Case of Tropospheric Ozone in Sub-Saharan Africa. (Bertinelli L \& Strobl E) at Public Economic Theory Conference (PET 13), Lisbon, Portugal, 5-7 July 2013.

\section{Arnaud Bourgain}

- From Tax Evasion to Tax Planning (Bourgain A, Pieretti, P \& Zanaj S), at Canadian Economics Association Conference, Montreal, Canada, 30 May-2 June 2013

\section{Jean-François Carpantier}

- Commodities Inventory Effect, at Workshop on Financial Risks, Orléans, France, 23-24 January 2013.

- Real Exchange Rates, Commodity Prices and Structural Factors in Developing Countries, at CSAE Conference 2013: Economic Development in Africa, Oxford, UK, 17-19 March 2013.

- Real Exchange Rates, Commodity Prices and Structural Factors in Developing Countries, at OxCarre Seminar Series (invited speaker), Oxford, UK, 29 May 2013.
- Measuring Trade Responses to Fiscal Policy, at Seventh Methods in International Finance Network Annual Workshop, Namur, Belgium, 23-24 September 2013.

- Specific Markov-Switching Behavior for ARMA Parameters, at Journées d'Econométrie: Développements Récents Appliqués à la Finance, Paris-Nanterre, France, 11 December 2013.

\section{Antonio Cosma}

- Valuing American Options Using Fast Recursive Projections, at Quantitative Economics Conference (QEC2013), Beijing, China, 16 July 2013.

\section{Denise Elaine Fletcher}

- The Promise of Relational Modes of Inquiry for Entrepreneurship Research. (Fletcher DE \& Selden P), at Advancing European Traditions in Entrepreneurship Studies, Leeds, UK , March 2013.

- 'I'll show them who's boss': A Critical Analysis of a Television Consultancy, at International Family Enterprise Research Academy, St. Gallen, Switzerland, July 2013.

\section{Yutao Han}

- On the desirability of tax coordination when countries compete in taxes and infrastructure, at 12th Journées Louis-André GérardVaret, Aix-en-Provence, France, 26-28 June 2013.

- On the desirability of tax coordination when countries compete in taxes and infrastructure, at Public Economic Theory Conference (PET13), Lisbon, Portugal, 5-7 July 2013.

- On the desirability of tax coordination when countries compete in taxes and infrastructure, at Singapore Economic Review Conference, Singapore, 5-8 August 2013.

\section{Katrin Hussinger}

- Resource Complementarity and Value Capture in Firm Acquisitions: The Role of Intellectual Property Rights (Grimpe C \& Hussinger K), at Max Planck Institute, Jena, Germany, 10-13 June 2013.

- Insider Trading and the Patent Application Process. (Hussinger, K, Keusch T \& Moers F), at DRUID Conference, Barcelona, Spain, 15-20 June 2013. 
- Resource Complementarity and Value Capture in Firm Acquisitions: The Role of Intellectual Property Rights. (Grimpe C \& Hussinger K), at Academy of Management Conference, Orlando, USA, August 2013.

- How valuable are Patent Blocking Strategies? (Czarnitzki D, Hussinger K, \& Leten B), at Asia-Pacific Innovation Conference, Taipei, Taiwan, 6-7 December 2013.

- Uncertain Intellectual Property Rights, Access to External Funding and New Product Development in Start-up Firms (Heger D \& Hussinger K), at National Taipei University, Taipei, Taiwan, December 2013.

\section{Andreas Irmen}

- Capital and Labour-Saving Technical Change in an Aging Economy, University of Trier, Germany, January 2013.

- Capital and labor saving technical change in an aging economy, Research Seminar CBS, Copenhagen Business School, Denmark, 22 April 2013.

- A generalized Steady-State Growth Theorem, Conference "Overlapping Generations Days", CERDI Clermont-Ferrand, France, 22-23 May 2013.

- Capital and Labour-Saving Technical Change in an Aging Economy, Association for Public Economic Theory (APET), International Meeting, Lisbon, Portugal, July 2013.

\section{Nicolas Jonard}

- Organizations and Emotions: Design, Contagion and Performance (Cowan R, Jonard N \& Wehuizen R), at 18th Workshop on Economies with Heterogeneous Interacting Agents, Reykjavik, June 2013.

\section{Christos Koulovatianos}

- Analytical Guidance for Fitting Parsimonious Household-portfolio Models to Data, at 8th NHH-UIO Workshop, Oslo, Norway, 5 June 2013.

\section{Anastasia Litina}

- Natural Land Productivity, Cooperation and Comparative Development, at CAGEICEPR Conference: Long-Run Growth: Unified Growth Theory and Economic History, Warwick, UK, 29-30 January 2013.
- Natural Land Productivity, Cooperation and Comparative Development, at University of Gothenburg's Research Seminar, Gothenburg, Sweden, March 2013.

- The Geographic Origins of State Formation, at University of Copenhagen's Research Seminar, Copenhagen, Denmark, March 2013.

- Natural Land Productivity, Cooperation and Comparative Development, at Deep Determinants of International Comparative Development, Brown University, USA, May 2013.

- Explicating Corruption and Tax Evasion: Reflections on Greek Tragedy (Litina A, Palivos T), at Conference on Research on Economic Theory and Econometrics, Athens University of Economics and Business, Naxos Greece, 14-18 July 2013

- Natural Land Productivity, Cooperation and Comparative Development, at NBER Summer Institute, Boston, USA, July 2013.

- Natural Land Productivity, Cooperation and Comparative Development, at European Economic Association, Gothenburg, Sweden, August 2013.

- Public Versus Private Education: Is There a Role for Institutions? (Litina A, Pantelis K \& Palivos T), at Econometric Society Summer Meeting, Gothenburg, Sweden, August 2013.

- Religiosity and Growth Revisited, at Economics and Business Research Seminar, University of Athens, Athens, Greece, December 2013.

- Natural Land Productivity, Cooperation and Comparative Development, at University of Namur's Research Seminar, 2013.

\section{Lukas Loehlein}

- What do we know about Audit Oversight Regulation? - A Review of 30 Years of U.S. Audit Oversight Literature, at 7th European Auditing Research Network (EARNet) Symposium, University of Trier, Trier, Germany, 27-28 September 2013.

\section{Anke Muessig}

- Disparities in Audit Pricing, at Research Seminar Oldenburg, Oldenburg, Germany, 21 November 2013.

\section{Erica Perego}

- Macroeconomic Determinants of European Stock and Government Bond Correlations: A Tale of Two regions (Perego E \& Vermeulen W), at European Economic Association (EEA) Conference, Goteborg, Sweden, 26-30 August 2013. 
- Macroeconomic Determinants of European Stock and Government Bond Correlations: A Tale of Two regions (Perego E \& Vermeulen W), at LEO seminar, University of Orleans, Orleans, France, 19 November 2013.

\section{Pierre M Picard}

- Sustainable Migration Policies, at Université Paris Cergy-Pontoise, Economic Department, Paris, France, January 2013.

- Commodity Taxation and Regulatory Competition (Picard PM, Moriconi S, \& Zanaj S), at Research Seminar, Sassari, Italy, 14 February 2013.

- Taxation and Regulatory Competition (Picard PM, Moriconi S \& Zanaj S), at FUSL lunch seminar, Brussels, Belgium, 28 February 2013.

- State Owned Firms: Private Debt, Cost Revelation and Welfare, at ECORE Seminar, Center for Economic Studies, KU Leuven, Belgium, February 2013.

- Spatial Segregation and Urban Structure, at Rieti Tokyo Workshop, Tokyo, Japan, 27 March 2013.

- Commodity Taxation and Regulatory Competition (Picard PM, Moriconi S \& Zanaj S), at Public Policies and Spatial Economics, Lyon, France, March 2013.

- Trade, Economic Geography and the Choice of Product Quality, at Second International Conference "Industrial organization and spatial economics", St. Petersbourg, Russia, June 2013.

- Social Interactions, Social Capital and Urban Structure, at North American Meetings of the Regional Science Association International, Atlanta, USA, 13-16 June 2013.

- Social Interactions, Social Capital and Urban Structure, at Public Economic Theory Conference (PET13), Lisbon, Portugal, July 2013.

- Commodity Taxation and Regulatory Competition (Picard PM, Moriconi S, \& Zanaj S), at Public Economic Theory Conference (PET13), Lisbon, Portugal, July 2013.

- Sustainable Migration Policies, at University of Lille 1, France, October 2013.

- Trade, Economic Geography and the Choice of Product Quality, at University of Bologna, Italy, October 2013.

- Commodity Taxation and Regulatory Competition, at University of California Irvine, Economic Department, USA, November 2013.
- Commodity Taxation and Regulatory Competition, at University of Strasbourg, France, November 2013.

\section{Patrice Pieretti}

- NATO Parliamentary Assembly, Patrice Pieretti, Attracting Investment and the Viability of Small Economies, Luxembourg, 18 May 2013.

\section{Laura Rovegno}

- Endogenous Trade Restrictions and Exporters' Pricing Behavior, at XIV Conference on International Economics, Palma de Mallorca, Spain, October 2013.

- Endogenous Trade Restrictions and Exporters' Pricing Behaviour , at XXVIII Jornadas de Economía Industrial, Segovia, Spain, October 2013.

- Endogenous Trade Restrictions and Exporters' Pricing Behaviour, at 8th Annual International Symposium on Economic Theory, Policy and Applications, Athens, Greece, October 2013.

\section{Henri Sneessens}

- Output and Welfare Effects of Fiscal Consolidation - A Discussion, at Belgian Macroeconomic Workshop, Leuven, Belgium, March 2013.

- Regional Unemployment Theory - A Discussion, at ESL Doctoral Workshop, Louvain-la-Neuve, Belgium, May 2013.

\section{Alessandro Tampieri}

- Students' Social Origins and Targeted Grade Inflation, at Public Choice Conference, location, 7-10 March 2013.

- Students' Social Origins and Targeted Grade Inflation, at Public Economic Theory Conference (PET13), Lisbon, Portugal, 5-7 July 2013.

- Arts vs Engineering: The Choice among Consumption and Investment in Education, at University of Florida' seminar, USA, 15 May 2013.

- Arts vs Engineering: The Choice among Consumption and Investment in Education (Tampieri A \& Romano R), at University of Bologna internal seminar, Italy, 10 July 2013. 


\section{Virginie Terraza}

- Long Memory and Regime Switching Beta Model for Hedge Fund Dynamics, at 7th CSDA International Conference on Computational and Financial Econometrics, Senate House, University of London, UK, 14-16 December 2013.

\section{Gautam Tripathi}

- Nonparametric Estimation of Returns to Scale. (Severini T \& Tripathi G), at Canadian Economics Association Annual Meeting, Montreal, Canada, 30 May-2 June 2013.

- Nonparametric Estimation of Returns to Scale. (Severini T \& Tripathi G), at International Year of Statistics Conference, Luxembourg, 27 November 2013.

\section{Skerkilajda Zanaj}

- (Un)stable Vertical Collusive Agreements (Zanaj S \& Gabszewicz J), at Industrial Organization Society Annual conference, Boston, USA, 1-5 May 2013.

- Carbon Tax, Pollution and Firms' Location (Exbrayat N, Riou S, \& Zanaj S), at St. Petersburg workshop on Environmental Economics, St. Petersburg, Russia, 1-5 October 2013.

\section{Benteng Zou}

- Threshold Preferences and the Environment, at IPAG Seminar, Paris, France, January 2013.

- On the Desirability of Tax Coordination when Countries Compete in Taxes and Infrastructures, at COST Action IS1104 IEU in the new economic complex geography: models, tools and policy evaluation", Lisbon, Portugal, April 2013.

- Asymmetric Competition among Nation States: A Differential Game Approach, at 2nd International Quantitative Economics and Finance Conference, Beijing, China, July 2013.

- Transboundary Pollution and Abatement(I) : The Target and its Dynamics, at Public Economic Theory Conference (PET13), Lisbon, Portugal, July 2013.

\section{E. Short-Term Visits}

- Robert Breunig, Australian National University: 30/01-02/02/2013

- Albrizio Silvia, European Institute Florence: 02/04-02/08/2013

- Fausto Galli, University Salerono: 02/02-15/02/2013; 20/11/2013

- Paco Marhuendua, University Carlos Madrid II: 02/0502/08/2013; 20/11-22/11/2013

- Serge Coulombe, University Ottawa: 02/09-04/09/2013

- Martin Hud, ZEW: 30/09-02/10/2013

- Joel Machado, Université catholique de Louvain: 04/11-06/12/2013

- Paola Pederzoli, Université de Genève: 27/10-31/10/2013; 18/11-21/11/2013

- Dimitri Paolini, Università di Sassari: 12/11-15/11/2013

- Andrea Attar, CNRS, Toulouse School of Economics: 16/12-17/12/2013

- Pierre Giot, Université de Namur: 18/12/2013

- Geoffroy De Clippel, Brown University: 18/12/2013 


\section{CREA in Society}

\section{Expert Reports}

NATO Parliamentary Assembly, Patrice Pieretti, Attracting Investment and the Viability of Small Economies, 18 May 2013.

\section{Letzebuerger Land Columns}

06/2011 - Muessig A

Mehr oder weniger - Was erwarten wir von Abschlussprüfern?

07/2011 - Bourgain A

Stratégies face à l'exode de personnel médical d'Afrique subsaharienne.

\section{9/2011 - Razafitombo H \& Terraza V}

Peut-on comparer la performance des fonds d'investissement selon leur domiciliation?

11/2011 - Pieretti P, Thisse J \& Zanaj S

Quand un paradis fiscal est-il un paradis fiscal ?

02/2012 - Beine M

Etudier à l'étranger : qui et pourquoi ?

\section{3/2012 - Bertinelli L}

Le climat peut-il être un facteur de (sous) développement?

Le cas de l'Afrique sub-Saharienne.

04/2012 - Picard PM

World Class University, made in Luxembourg.

07/2012 - Irmen A

Wie glücklich ist das Land? Zum Zusammenhang von Geld und Glück.
03/2014 - Hussinger K

Die Strategische Bedeutung von Patenten.

\section{CREA in the Media in 2013}

- Aux services de l'industrie, Interview of Arnaud Bourgain, PaperJam, January 2013, p. 30-31.

- Index plafonné : suites difficiles à prévoir selon un expert, Interview of Arnaud Bourgain, RTL, 13 March 2013.

- Luxembourg is well placed in fostering the travel of entrepreneurial ideas, Interview of Denise E Fletcher in Merkur, Chambre of Commerce, March 2013.

- Dossier Grèce: "Il faut relâcher les mesures d'austérité" Interview of Christos Koulovatianos, Le Quotidien, 26 March, 2013.

- Fin du secret bancaire et diversification de l'économie luxembourgeoise, Interview of Arnaud Bourgain , RTS (Radio Télé Suisse), 11 April, 2013.

- New book reveals innovative method of managing investment funds, Interview of Virginie Terraza, by Britta Schluetter, idw-online.de, 13 June 2013.

- Pas très optimiste sur l'avenir de l'euro, Interview of Paul De Grauwe by Frédéric Antzorn, PaperJam, 22 November 2013.

- Banks and Governments: The Deadly Embrace, Article by Margaret Ferns for Wort.Lu, 25 November 2013.

- La BCE doit accentuer l'assouplissement quantitatif, Article by Laurent Moyse, Luxemburger Wort, 25 November 2013.

- 100 ans de politique pragmatique, Interview of Henri Sneessens, by Linda Cortey, Luxemburger Wort, 20 December 2013.

\section{9/2012 - Zou B \& Pieretti P}

Politique d'Attractivité et Viabilité des Petites Economies.

\section{2/2012 - Jonard N}

Innovation et créativité dans les petits mondes.

04/2013 - Tripathi G \& Xenia M

Macht Junk Food abhängig? Eine Frage nicht nur für Mediziner

09/2013 - Fletcher DE

Les couples en affaires.

01/2014 - Cosma A

Algorithmes et marchés d'options. 



\section{Contact}

UNIVERSITY OF LUXEMBOURG

FACULTY OF LAW, ECONOMICS AND FINANCE CREA

148, av. de la Faïencerie

L-1511 Luxembourg

T. (+352) 466644 6139/6336/6283

F. $(+352) 4666446341$

E. crea@uni.lu 

